Article

\title{
Trade Credit Financing and Sustainable Growth of Firms: Empirical Evidence from China
}

\author{
Li Huang, Qianwei Ying *, Shanye Yang and Hazrat Hassan \\ Business School, Sichuan University, Chengdu 610065, China; huangli2018@stu.scu.edu.cn (L.H.); \\ yangsy@stu.scu.edu.cn (S.Y.); hassan2018@stu.scu.edu.cn (H.H.) \\ * Correspondence: yingqw@scu.edu.cn
}

Received: 13 January 2019; Accepted: 8 February 2019; Published: 16 February 2019

\begin{abstract}
As an effective substitute for bank credit to ease financing constraints, trade credit plays an important role in the operation and growth of enterprises. This paper extends the literature by providing evidence on the relationship between trade credit financing and firm-level sustainable growth. Using the financial statement data of 20,089 Chinese A-share listed firms over the period 2003 to 2017, running a regression using the cross-section regression method and employing the two-stage instrumental-variable regression method in the endogeneity test, the study finds that trade credit has an overall positive and significant impact on the sustainable growth of Chinese firms, especially for firms with higher internal control ability, trade credit financing contributes more to sustainable growth, and the same way with private enterprises, whose growth depends more on trade credit compared to state-owned firms. We further find that the link between trade credit financing and sustainable growth of a firm is stronger in areas with lower access to finance, suggesting that firms with higher dependence on trade credit financing exhibit higher rates of sustainable growth in areas with weaker financial institutions.
\end{abstract}

Keywords: trade credit; sustainable growth of firms; internal control quality; financial market developmental level

\section{Introduction}

A large literature has examined the importance of financing for firm growth [1-3], and informal finance offers informational advantages whereas formal finance is scalable [4]. Prior studies have also shown that trade credit serves an important form of alternative financing, especially for firms facing asymmetric information, financial constraints, liquidity shocks or distress risk [5-8]. Trade credits, as a common credit relationship formed in the normal business activities and commodity transactions of enterprises, are a type of credit provided to customers when payment of sales products is deferred and are also one of the most important short-term fund sources of enterprises. From the perspective of financing, the essence of trade credits is a type of short-term credit with a relaxation effect on financing constraints that is provided to downstream enterprises by upstream enterprises. In developing countries whose financial development is suppressed, trade credits are available as an effective alternative mechanism for bank credits to ease financial constraints [9]. Due to the lack of an imperfect financial system, financing difficulties have been one of the bottlenecks for the development of enterprises in China. In this case, trade credits, as a financing alternative channel, are particularly important for enterprises in China [10]. While a growing literature began to focus on the usage and supply mechanisms of trade credit in developing economies without well-established financial markets [11-14], few papers have paid attention to the role trade credits played in firm growth in these developing economies. Fisman and Love [3] provided evidence for the positive effect of trade credit on industry growth in countries with weaker financial institutions, but unfortunately their evidence 
was industry-level instead of firm-level. Annalisa et al. [15] found a significant and positive role of trade credit in firm growth, but their evidence was based on a sample of eight developed European countries instead of developing ones. Even though Franklin Allen [16] has found that constructive informal financing such as trade credit corresponds to good firm performance in China, there's still little evidence on how credit trade affects firm's sustainable growth.

The purpose of our research is to address this important gap in the literature and figure out the contribution trade credit financing has made to the sustainable growth of firms in China. We ask three main interrelated questions regarding different ownership, different internal control quality of enterprises and different levels of financial market development. In particular, we want to answer the following questions: First, does trade credit have an impact on the sustainable growth of Chinese firms? Second, do the characteristics that exist in different corporates, such as state ownership and corporate internal control quality, affect the contribution trade credit makes to the sustainable growth? Finally, how can the different regional institutional environments, and various levels of regional financial development in different provinces in China affect the sustainable growth of firms, driven by trade credits?

We test the above questions using the Shanghai and Shenzhen A-share listed companies' data from 2003 to 2017. Following the methodology of Mohammad and Rahaman [17], we construct our empirical model and find a significant positive relationship between trade credit and sustainable growth of firms, after controlling for firm-level characteristics, province-level factors, industry effects and year factors. This result has statistical and economic implications and supports the contention that sustainable growth of firms relies more on trade credit when firms have higher internal control quality or are private enterprises, especially in areas with a low degree of marketization.

Our research contributes to understanding how and to what extent trade credit financing supporting the sustainable growth and economic activities of Chinese enterprises in the setting of China's transition economy. Specifically, this research has two aspects of meaning. First, while existing studies show alternative financing features and mechanisms provided by trade credits in the Chinese context $[10,18]$, few studies directly study whether trade credit can promote sustainable growth of enterprises. Our study supplements earlier research of trade credit policies and provides the first evidence of its importance in the sustainable growth of a firm. Second, regarding the internal characteristics of enterprises and the external institutional environment, we test whether there are differences in promoting firm sustainability depending on the use of trade credit, and to foster sustainable growth, we provide references for enterprises to improve their internal characteristics, especially internal control quality, as well as actively adapting to the institutional environment.

The remainder of the research is organized as follows. We first review the literature and develop our hypotheses in Section 2. Then we discuss our data and the methodology in Section 3. Finally, we present our empirical results in Section 4 and conclude the research in Section 5.

\section{Literature Review and Hypotheses Development}

A large literature uses different research methods and data to prove that a country's financial market development and economic growth are closely related [19,20]. Rajan and Zingles [21] emphasize the view that financial institutions promote economic growth by improving resource allocation. They find that industrial sectors that are primarily dependent on external financing develop faster in countries with developed finance systems. However, in addition to formal financial channels, enterprises that are experiencing financial constraints can also use trade credits and other informal financing channels. Prior research supports this view, and indicates that trade credit is an important form of alternative financing for enterprises [22,23]. Fisman and Love [3] find that in areas with weaker development of financial intermediations, industries that rely largely on trade credits experience higher growth rates. For enterprises that provide trade credit, the insured receivables also enable them to achieve bank contracts, allowing them to draw on short-term liabilities with receivables as pledged collateral [15]. We thus can reasonably assume that trade credits can make a significant contribution 
to the sustainable growth of enterprises, just as bank credits do. Besides, trade credit promotes scale efficiency by alleviating financing constraints and achieves larger scale efficiency than bank borrowing through resource allocation mechanisms, which can improve the production efficiency of enterprises, and then promote the improvement of profitability and performance of enterprises. Thus, based on the above discussion, we develop the first hypothesis:

Hypothesis 1. In general, trade credit financing is conducive to the sustainable growth of enterprises.

In China, there are at least two factors explaining the fact that the growth of private enterprises is more dependent on trade credit financing than that of state-owned enterprises. First, the government in China, particularly local governments, still intervenes greatly on economic activities and resource allocations. One of the common scenarios is that local governments provide preferential loans for state-owned enterprises within the jurisdiction through the intervention of the credit decisions of state-owned banks $[21,24,25]$. Moreover, state-owned enterprises are more likely to enjoy policy preferences in the product market and factor market than private enterprises [26,27]. Additionally, state-owned enterprises can more easily enter into regulated and monopolistic industries, as well as obtaining government procurement contracts. Thus, state-owned enterprises usually develop without relying on trade credit financing. With respect to state-owned enterprises, private enterprises generally encounter credit constraints and have harder access to bank loans [10,28,29]. The shortage of funds severely restricts the development of Chinese private enterprises and becomes a bottleneck restricting the further development of China's private economy. In particular, for small and medium private enterprises with insufficient financial support, it is difficult for them to obtain effective financing through formal channels. Private enterprises obtain relatively less financing from banks and capital markets, whereas the capital allocation of China's formal finance system cannot explain the constant and rapid growth of the private economy. Thus, some scholars have concluded that trade credits serve as a significant financing source for the growth of private enterprises [30,31]. Second, due to the imperfect internal property incentives system and governance structures in China, there often exists a phenomenon of over-investment and low efficiency in the use of funds by state-owned enterprises [29]. Compared with state-owned enterprises, private enterprises are more efficient in the use of funds. Based on the above analysis, we expect that trade credit financing contributes more to private enterprises than to state-owned enterprises, and the following assumption is formed:

Hypothesis 2. Compared with state-owned enterprises, trade credit financing contributes more to sustainable growth of private enterprises.

As documented by prior studies, internal control serves as an important index to measure the level of corporate governance, hence the quality of internal control does have a significant impact on the acquisition and use of trade credit [32]. Anna M. Costello and Regina Wittenberg-Moerman [33] show that firms with strong internal control quality will provide a higher quality of accounting information, which can partly alleviate the information asymmetry, and further enhance the trust between trading partners, and make it much easier for enterprises to obtain trade credit financing. Prior literatures support this view and show that firms without material internal control weaknesses have higher accrual quality, lower profitability of insider trading and higher operational efficiency [34,35]. This finding illustrates that, well-designed firms may improve outsiders' perceptions of their quality compared with firms with lower level of internal control. Moreover, internal control helps to improve the business decision quality as a formal institutional arrangement [36], and increase the efficiency of resource allocation, as well as enhance the corporate governance and reduce the corporate risk-taking and idiosyncratic risk [37-39], and effective internal control system also play a role in enhancing firm value and performance in political shocks [40]. Therefore, we predict that, relative to enterprises with lower internal control quality, firms with higher internal control quality can obtain more trade credit, which will increase the efficiency of resource allocation, improve the level of corporate governance 
and finally enhance the contribution of trade credit to the sustainable growth of enterprises. Hence, we hypothesize the following:

Hypothesis 3. Compared with enterprises with lower internal control quality, trade credit financing contributes more to the sustainable growth of enterprises with higher internal control ability.

As an informal financing alternative mechanism in financial markets, the contributions trade credit financing made to firm growth are closely related to the development of the credit markets [41]. The required financing for firm growth would be more from banking credit funds rather than from trade credit financing when the credit market is developed. The lower the level of the credit market, the worse the decision-making ability of the bank. As a result, enterprises are more vulnerable to facing credit constraints and needing to turn to alternative financing methods, for example, trade credits, and they become even more dependent on trade credit financing [3]. To be specific, in our research setting, the development trend of China's credit market shows horizontal differential characteristics, which means, there is a large difference in the market environment factors such as the developmental level of the financial market (mainly referring to the developmental level of the credit market and competitiveness of financial industry) among various provinces and regions in China. With respect to the provinces with less developed financial markets, provinces with more developed financial markets tend to have more highly developed financial systems, relatively more financing channels for enterprises, and more access to banking credit in the market-oriented conditions [10]. Therefore, we expect that in regions with less developed credit markets and more fierce financial competition, the sustainable growth of a firm will be more dependent on trade credit. In summary, we propose the following hypotheses:

Hypothesis 4. Compared with regions with more developed financing market, trade credit financing contributed more greatly to sustainable growth of firm in regions with less developed financing market.

\section{Methodology}

\subsection{Sample and Data}

This research selects China's A-share listed companies from 2003 to 2017 as the original sample and eliminates the following observations: (1) financial listed companies; (2) the firms with special treatment or particular transfer (ST or PT firms); (3) main variables data missing. To eliminate the effects of variable outliers, we also winsorize all main financial variables at the top and bottom $1 \%$. Ultimately, we obtained 20,089 observations. The main data of the variables used in this paper come from the China Stock Market and Accounting Research Database (CSMAR). The financial development level index comes from the Wind Database. The internal control quality index comes from the DIBO Database, a well-known database on internal control of listed firms in China. The instrumental variables, the level of social trust (Trust) come from China Comprehensive Social Survey (CGSS), and the number of chambers of commerce (Business) come from Chamber of Commerce Research Database (CCCD).

\subsection{Variables Definitions}

The dependent variable "sustainable growth of firm", denoted as SGR, measures the long-term profitability and lasting competitiveness of enterprises. Higgins first put forward the conception of sustainable growth rate from the perspective of financial management, which is defined as the maximum growth rate of a firm's sales without exhausting its financial resources [8]. While Van Horne believes that the sustainable growth rate is the largest annual growth percentage of enterprise sales under a certain operating and debt-to-dividend ratio, by emphasizing that sustainable growth rate is the target value rather than the actual value [9]. Referring to prior studies [41-43], we adopt Van Horne's static model of sustainable growth rate, as mentioned above, the SGR is contrasted under 
the condition of not exhausting financial resources while the company's sales can increase by the largest proportion. In a robustness test, we used Higgins' model [44] to calculate the sustainable growth rate. Additionally, we measured the main explanatory variable "trade credit" (TC) as the sum of accounts payable, notes payable and advance receivable scaled by total assets, which is widely used in China [45].

The control variables used in this paper refer to existing research on firm growth $[1,3,17,46]$, including the natural logarithm of firm size (Lnasset), firm age (Lnage), the net profit margin on sales (Profit), short-term and long-term financial leverage (Sloanratio and Lloanratio), cash flow (Cashratio), financial slack $(F s)$, current ratio (Currentratio), internal fund (Interfund) and corporate governance factor, that is, the natural logarithm of internal control quality index (Lnindex), the shareholding ratio of the largest shareholder (First) and size of board directors (Lndirector). In the test for the different contributions of trade credit to sustainable growth of firms under different levels of financial market development in different provinces, we use the developmental level of credit market and the level of competitions in the finance industry to measure the level of financial market development in the province. The specific meaning of each variable is presented in Table 1.

Table 1. The definitions of the main variables.

\begin{tabular}{|c|c|}
\hline Variables & Definitions \\
\hline$S G R$ & $\begin{array}{l}\text { The sustainable growth rate is change in equity scaled by beginning-of-period equity, } \\
\text { which can be presented by the formula: } S G R=\mathrm{P} \times \mathrm{A} \times \mathrm{T} \times \mathrm{R} /(1-\mathrm{P} \times \mathrm{A} \times \mathrm{T} \times \mathrm{R}) \text {, } \\
\mathrm{P} \text { represents the profit margin (profit scaled by total sales), } \mathrm{A} \text { represents the asset } \\
\text { turnover ratio(total sales scaled by total assets), T represents the leverage factor (total } \\
\text { assets scaled by end-of-period equity) and } \mathrm{R} \text { represents the retention ratio (retained } \\
\text { earnings scaled by profit) }\end{array}$ \\
\hline SGR1 & $\begin{array}{l}\text { The sustainable growth rate is change in equity scaled by beginning-of-period equity, } \\
\text { which can be presented by the following formula: } S G R 1=\mathrm{P} \times \mathrm{A} \times \mathrm{T}_{0} \times \mathrm{R} \text {, } \\
\mathrm{P} \text { represents the profit margin (profit scaled by total sales), } \mathrm{A} \text { represents the asset } \\
\text { turnover ratio (total sales scaled by total assets), } \mathrm{T}_{0} \text { represents the leverage factor (total } \\
\text { assets scaled by beginning-of-period equity) and } \mathrm{R} \text { represents the retention ratio } \\
\text { (retained earnings scaled by profit) }\end{array}$ \\
\hline TC & $\begin{array}{l}\text { The sum of accounts payable, notes payable and advance receivable scaled by } \\
\text { total assets }\end{array}$ \\
\hline Lnasset & The natural $\log$ of total assets of the firm \\
\hline Lnage & The natural log of age, which means the age of the firm (in years) since incorporation \\
\hline Sloanratio & The short-term bank loans scaled by total assets \\
\hline Lloanratio & The long-term debt scaled by total asset \\
\hline Fs & Financial Slack, which is defined as "(Tangible Assets/Total Liabilities) - 1" \\
\hline & $\begin{array}{l}\text { Dummy variable, which equals } 1 \text { if a firm's ultimate shareholder is a government, and } \\
0 \text { otherwise. }\end{array}$ \\
\hline Interfund & Internal fund, which is defined as $\log \left(\right.$ Owner's Equity $\left._{t}\right)-\log \left(\right.$ Owner's Equity $\left._{t-1}\right)$ \\
\hline Currentratio & The current assets scaled by current liabilities \\
\hline profit & Net Profit Margin on Sales in the end of the previous year \\
\hline cashratto & Net operating cash flow scaled by total assets \\
\hline & The natural log of internal control quality index \\
\hline First & The shareholding ratio of the largest shareholder \\
\hline Lndirector & The natural $\log$ of the numbers of board directors \\
\hline Creditmarket & The development level of credit market \\
\hline Bankcomp & The level of competitions in the finance industry \\
\hline Trust & The natural log of level of social trust \\
\hline Business & The natural log of numbers of different chamber of commerce \\
\hline
\end{tabular}




\subsection{Algebraic Model}

The basic empirical model used in this study is developed on the basis of Fisman and Love [3]. The main regression model is shown in Equation (1):

$$
S G R_{i t}=\alpha+\beta_{1} T C_{i t}+\sum_{j=2}^{J} \beta_{j} X_{i t}+\sum \gamma \text { Industry }_{i t}+\sum \lambda \text { Province }_{i t}+\varepsilon_{i t}
$$

$S G R_{i t}$ represents sustainable growth of firm rate in year $\mathrm{t}$, which is measured by Van Horne's static model and Higgins' sustainable growth rate model in the robustness test. The main explanatory variable $T C_{i t}$ represents trade credit financing, which is defined as the sum of accounts payable, notes payable and advance receivable scaled by total assets in year t. $\alpha$ is a constant term, while $\varepsilon_{i t}$ is a stochastic disturbance term. The efficient $\beta_{1}$ reflects the sensitivity of the sustainable growth of firm rate to trade credit. $X$ represents other control variables including the factors that may affect the $S G R$ such as firm profitability, firm size, leverage, firm age, cash flow, corporate governance factor, and so on. In addition, model (1) also controls for the industry and regional dummy variables, namely, Industry and Province.

We primarily focus on the cross-sectional differences of sustainable growth of firm and the contribution of trade credit to firm sustainability. Thus, we employ the cross-sectional regression method introduced by Fama and MacBeth [47], running a cross-sectional regression on each year's sample of firms, followed by taking the average of the regression coefficients of each year.

On the basis of the basic regression model, we run subgroup regressions to study whether the contribution of trade credit financing to sustainable growth of firm is significantly different in the situation of different nature of ownership and internal control quality. The ownership can be divided into two types: state-owned enterprises and private enterprises, and the internal control quality group is distinguished by the median of internal control quality. We also conduct regressions on different provinces to test the contribution of trade credit financing to sustainable growth of firm in different credit market and financial development levels. We take the median of the credit market index as the cut-off point of high or low regional credit market developmental level, similarly we also take the median of degree of competition in the financial industry as the cut-off point of high or low regional financial development level.

\section{Results}

\subsection{Descriptive Statistics}

The descriptive statistics are presented in Table 2, SGR is about $6.1 \%$ on average for the period 2003-2017, all firms in the sample use trade credit with the mean (median) level of trade credit (TC) is $0.161(0.13)$ with a standard deviation of 0.12 , and compared with the figure for short-term loans (mean of 0.11 ), the use of trade credit is much higher in China. The average firm has about $11.1 \%$ of total assets in short-term loans and $4.7 \%$ of total assets in long-term loans, and the average internal fund is about $13 \%$, which shows that the firms rely heavily on the short-term and internal financing. The mean value of sample firms' logarithm of total assets is about 22, which may account for the large average asset portfolio of firms, and firms' logarithm of age is about 2.523. The average annual net profit margin on sales is about $10 \%$, with a relatively low cash coverage ratio (mean Cashratio $=0.05$ ). The shareholding ratio of the largest shareholder is relatively high (mean First $=0.364$ ), which indicates the significant role of the largest shareholder plays in current China, and the average logarithm of internal control quality index is 6.52; the higher the index is, the more effective of internal control system is.

Further, in order to have a visually description of the relationship between trade credit and sustainable growth of firm, we draw a picture according to the mean use of trade credit and sustainable growth of firm for the period 2003-2017. As illustrated in Figure 1, the movement trend of the mean 
value of $S G R$ in each year and the average $T C$ are almost the same, suggesting that trade credit is really associate with sustainable growth of firm.

Table 2. Descriptive statistics.

\begin{tabular}{ccccccccc}
\hline Variable & $\mathbf{N}$ & Mean & SD & Min & p25 & p50 & p75 & Max \\
\hline SGR & 20089 & 0.061 & 0.072 & -0.175 & 0.021 & 0.051 & 0.091 & 0.317 \\
TC & 20089 & 0.161 & 0.120 & 0.006 & 0.070 & 0.130 & 0.221 & 0.555 \\
Lnasset & 20089 & 22.001 & 1.231 & 19.907 & 21.102 & 21.807 & 22.682 & 25.947 \\
Lnage & 20089 & 2.523 & 0.450 & 1.099 & 2.303 & 2.565 & 2.833 & 3.296 \\
Fs & 20089 & 0.999 & 2.791 & -1.030 & -0.481 & 0.037 & 1.214 & 16.523 \\
Interfund & 20089 & 0.130 & 0.213 & -0.259 & 0.023 & 0.069 & 0.151 & 1.120 \\
Currentratio & 20089 & 2.309 & 2.451 & 0.291 & 1.079 & 1.536 & 2.474 & 16.220 \\
Lnindex & 20089 & 6.520 & 0.110 & 6.186 & 6.465 & 6.527 & 6.574 & 6.836 \\
First & 20089 & 0.364 & 0.152 & 0.091 & 0.241 & 0.344 & 0.475 & 0.748 \\
Sloanratio & 20089 & 0.111 & 0.107 & 0 & 0.013 & 0.086 & 0.177 & 0.427 \\
Lloanratio & 20089 & 0.047 & 0.079 & 0 & 0 & 0.006 & 0.062 & 0.377 \\
Lndirector & 20089 & 2.175 & 0.203 & 1.609 & 2.079 & 2.197 & 2.197 & 2.708 \\
Cashratio & 20089 & 0.050 & 0.070 & -0.151 & 0.010 & 0.048 & 0.091 & 0.246 \\
Profit & 20089 & 0.100 & 0.125 & -0.274 & 0.028 & 0.074 & 0.150 & 0.583 \\
\hline
\end{tabular}

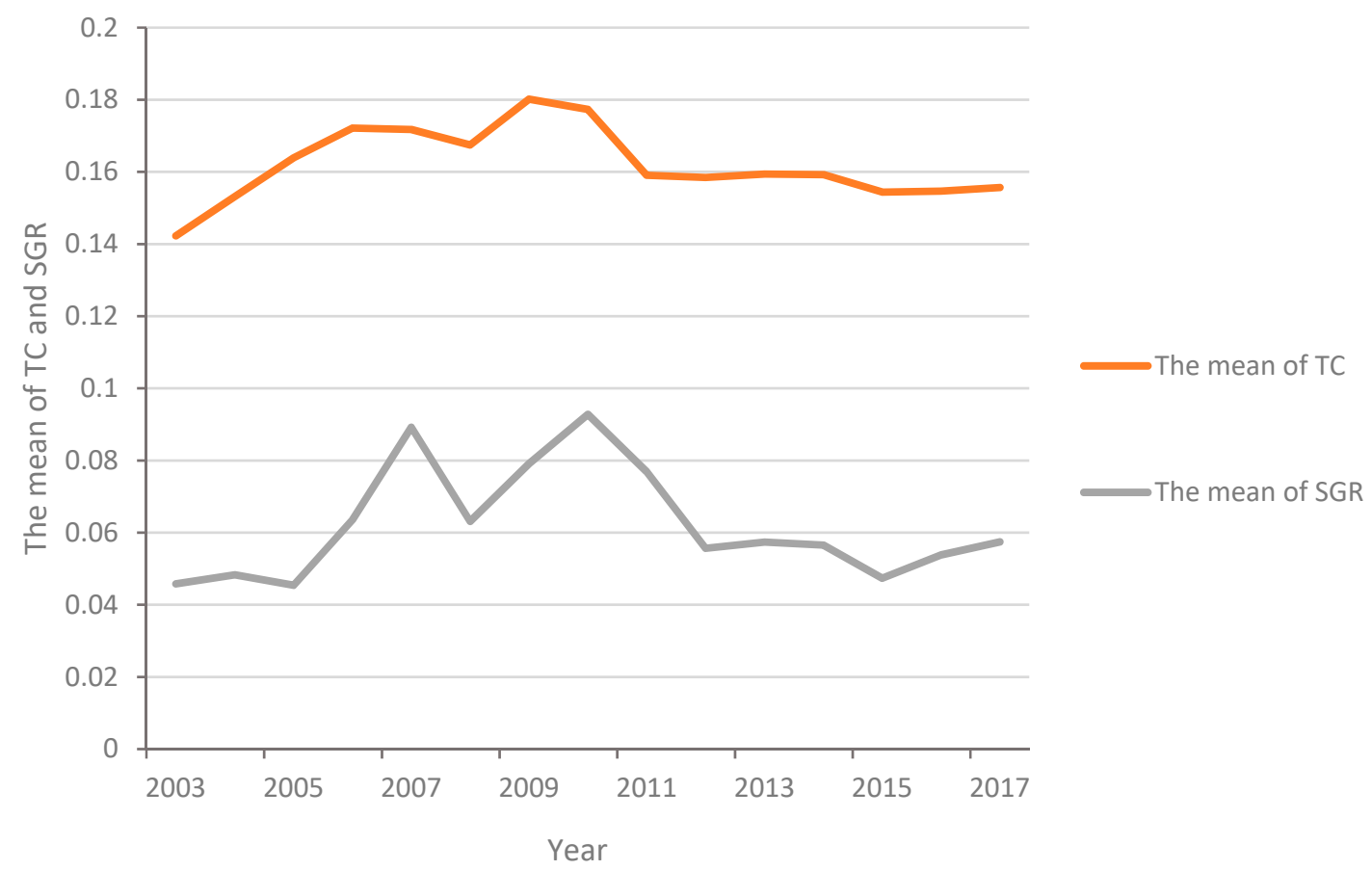

Figure 1. The trend of trade credit and sustainable growth of firm.

\subsection{Regression Results}

First, we study the relationship between trade credit financing and sustainable growth of a firm, and the sustainability of this impact; namely we examine how long this effect has existed and whether trade credit will affect SGR for the following one, two and three periods. Besides, this can also partially alleviate endogenous problems, where $S G R$, in turn, may affect the availability of trade credit provided by partner suppliers. Then, we run the regression using the cross-section regression method proposed by Fama and MacBeth [47], and specific regression results are as shown in Table 3. 
Table 3. Regression of Sustainable growth of firm on Trade Credit: Baseline Results.

\begin{tabular}{|c|c|c|c|c|}
\hline & (1) & (2) & (3) & (4) \\
\hline Variables & $S G R_{t}$ & $S G R_{t+1}$ & $S G R_{t+2}$ & $S G R_{t+3}$ \\
\hline \multirow[t]{2}{*}{$T C$} & $0.108^{* * *}$ & $0.100^{* * *}$ & $0.085^{* * *}$ & $0.079 * * *$ \\
\hline & $(17.250)$ & (11.327) & $(9.696)$ & $(5.736)$ \\
\hline \multirow[t]{2}{*}{ Lnasset } & $-0.007^{* * *}$ & $-0.003^{*}$ & $-0.004^{* *}$ & $-0.005^{* *}$ \\
\hline & $(-4.081)$ & $(-1.952)$ & $(-2.327)$ & $(-2.260)$ \\
\hline \multirow[t]{2}{*}{ Lnage } & 0.001 & 0.001 & $0.003^{* *}$ & $0.004^{* *}$ \\
\hline & $(0.585)$ & $(0.974)$ & $(3.026)$ & $(2.214)$ \\
\hline \multirow[t]{2}{*}{ Fs } & $-0.004^{* * *}$ & $-0.003^{* * *}$ & $-0.003^{* * *}$ & $-0.003^{* * *}$ \\
\hline & $(-16.091)$ & $(-9.232)$ & $(-4.484)$ & $(-4.323)$ \\
\hline \multirow[t]{2}{*}{ Interfund } & $0.082 * * *$ & $0.058^{* * *}$ & $0.041^{* * *}$ & 0.019 \\
\hline & (5.093) & $(5.561)$ & $(3.852)$ & $(1.692)$ \\
\hline \multirow[t]{2}{*}{ Currentratio } & $0.001^{* * *}$ & $0.002^{* * *}$ & $0.002^{* * *}$ & $0.003^{* * *}$ \\
\hline & $(3.231)$ & (3.939) & (3.139) & $(3.556)$ \\
\hline \multirow[t]{2}{*}{ Lnindex } & $0.189 * * *$ & $0.092^{* * *}$ & $0.082^{* * *}$ & $0.070 * * *$ \\
\hline & $(12.278)$ & $(7.843)$ & (5.655) & $(3.884)$ \\
\hline \multirow[t]{2}{*}{ First } & $-0.010^{* * *}$ & $-0.007^{*}$ & -0.004 & -0.005 \\
\hline & $(-4.486)$ & $(-1.895)$ & $(-0.890)$ & $(-0.942)$ \\
\hline \multirow[t]{2}{*}{ Sloanratio } & $0.032 * * *$ & 0.005 & 0.002 & 0.009 \\
\hline & $(3.631)$ & $(0.591)$ & $(0.171)$ & $(0.863)$ \\
\hline \multirow[t]{2}{*}{ Lloanratio } & $0.031^{* * *}$ & $0.023^{* *}$ & 0.022 & 0.025 \\
\hline & $(3.768)$ & $(2.348)$ & $(1.660)$ & (1.456) \\
\hline \multirow[t]{2}{*}{ Lndirector } & $-0.007^{* *}$ & -0.006 & -0.004 & -0.005 \\
\hline & $(-2.748)$ & $(-1.725)$ & $(-1.043)$ & $(-1.135)$ \\
\hline \multirow[t]{2}{*}{ Cashratio } & $0.113^{* * *}$ & $0.156^{* * *}$ & $0.142^{* * *}$ & $0.128^{* * *}$ \\
\hline & (13.872) & (15.770) & $(10.822)$ & (12.853) \\
\hline \multirow[t]{2}{*}{ Profit } & $0.265^{* * *}$ & $0.159^{* * *}$ & $0.133^{* * *}$ & $0.106^{* * *}$ \\
\hline & $(21.571)$ & $(17.389)$ & $(13.132)$ & $(8.960)$ \\
\hline \multirow[t]{2}{*}{ Constant } & $-1.065^{* * *}$ & $-0.497^{* * *}$ & $-0.410 * * *$ & $-0.343^{* * *}$ \\
\hline & $(-14.003)$ & $(-6.419)$ & $(-5.697)$ & $(-3.912)$ \\
\hline Industry & control & control & control & control \\
\hline Province & control & control & control & control \\
\hline Observations & 20,089 & 17,539 & 15,358 & 13,430 \\
\hline$R$-squared & 0.529 & 0.268 & 0.204 & 0.163 \\
\hline Number of groups & 15 & 14 & 13 & 12 \\
\hline
\end{tabular}

Notes: All regressions in this table employ the cross-sectional method introduced by Fama-MacBeth (1973), and the sample period is from 2003 to 2017 . The dependent variable is SGR. T statistics are in parentheses. ${ }^{*}, * *$, and ${ }^{* * *}$ represent statistical significance at the $10 \%, 5 \%$, and $1 \%$ levels, respectively.

As seen in the first column in Table 3, the coefficient on TC is positive and statistically significant at the $1 \%$ level; this suggests that in general, the trade credit financing influences SGR considerably. To be specific, the coefficient reported indicates that the increasing TC (trade credit) by one standard deviation increases SGR (sustainable growth of firm) by about $1.30 \%(0.12 \times 0.108)$. As indicated in the regression results in Columns (2), (3) and (4), the current trade credit has a significant impact on the sustainable growth rate of the next three periods, but the coefficient on TC gradually decreases, indicating that the impact of trade credit on the sustainable growth of enterprises in the future is gradually attenuated with time. This verifies Hypothesis 1 proposed above. This result is consistent with existing literature that indicated that trade credit financing can promote the economic growth of firms [3,19,21,22]. In Table 3, the coefficients on control variables, namely, Profit, Interfund, Currentratio, Lnindex, Sloanratio, Lloanratior and Cashratio are positive and significant, indicating that they contribute to the sustainable growth of firms. While other control variables, such as Lnasset, Fs, Lndirector, and First, the coefficients on them are significantly negative, suggesting that the higher of their value, the lower sustainable growth of firm is.

Furthermore, to verify Hypothesis 2, by adopting the literature method of current practice, we conducted regression tests on each of the samples of state-owned and private enterprises. The ownership nature of enterprises was classified according to the properties of the ultimate controller. We set an indicator variable Soe, which equals 1 if a firm's ultimate shareholder is government, and 
0 otherwise. The regression results are shown in Columns (1) and (2) in Table 4. The coefficients on $T C$ are positive and statistically significant at the $1 \%$ level for both state-owned enterprises and private enterprises, suggesting that trade credit financing has a significant positive impact on the sustainable growth of a firm regardless of ownership. To be specific, the estimated coefficient indicates that a one standard deviation increase in TC, corresponds to a $1.14 \%(0.12 \times 0.095)$ increase in $S G R$ for state-owned firms and a $1.55 \%(0.12 \times 0.129)$ increase in $S G R$ for private firms. To be specific, compared with the state-owned enterprises group, the coefficient on TC is $35.8 \%$ greater than that of state firms. Further, the coefficient difference across the two subsamples is statistically significant, with a $p$-value of less than 10 percent based on the Permutation test. This shows that, compared with the state-owned enterprises, private enterprises' sustainable growth relies more on trade credit. This result is consistent with the most existing research, which has suggested that private enterprises generally encounter credit constraints and have harder access to bank loans [27-29], hence trade credits serve as a significant financing source for the growth of private enterprises [30,31], and is in line with our expectation as well as Hypothesis 2 presented in the above theoretical analysis.

Table 4. Regression of Sustainable growth of firm on Trade credit: grouping according to ownership and internal control quality.

\begin{tabular}{|c|c|c|c|c|}
\hline & (1) & (2) & (3) & (4) \\
\hline Variables & Soe $=1$ & Soe $=0$ & High-index & Low-index \\
\hline TC & $\begin{array}{l}0.095^{* * *} \\
(11.999)\end{array}$ & $\begin{array}{l}0.129 * * * \\
(10.452)\end{array}$ & $\begin{array}{l}0.136^{* * *} \\
(16.073)\end{array}$ & $\begin{array}{c}0.069 * * * \\
(9.260)\end{array}$ \\
\hline Lnasset & $\begin{array}{c}-0.009 * * * \\
(-5.900)\end{array}$ & $\begin{array}{l}-0.006^{*} \\
(-1.903)\end{array}$ & $\begin{array}{c}-0.012 * * * \\
(-5.307)\end{array}$ & $\begin{array}{c}-0.006^{* * *} \\
(-4.108)\end{array}$ \\
\hline Lnage & $\begin{array}{c}0.004^{* *} \\
(2.481)\end{array}$ & $\begin{array}{l}0.000 \\
(0.218)\end{array}$ & $\begin{array}{c}0.001 \\
(0.934)\end{array}$ & $\begin{array}{c}0.001 \\
(0.445)\end{array}$ \\
\hline Fs & $\begin{array}{c}-0.005^{* * *} \\
(-7.552)\end{array}$ & $\begin{array}{l}-0.003^{* *} \\
(-2.761)\end{array}$ & $\begin{array}{c}-0.005^{* * *} \\
(-8.546)\end{array}$ & $\begin{array}{c}-0.003^{* * *} \\
(-9.138)\end{array}$ \\
\hline Interfund & $\begin{array}{c}0.086^{* * *} \\
(5.930)\end{array}$ & $\begin{array}{c}0.082^{* * *} \\
(3.477)\end{array}$ & $\begin{array}{c}0.065^{* * *} \\
(4.566)\end{array}$ & $\begin{array}{c}0.105^{* * *} \\
(4.641)\end{array}$ \\
\hline Currentratio & $\begin{array}{c}0.003^{* * *} \\
(4.884)\end{array}$ & $\begin{array}{c}0.001 \\
(0.967)\end{array}$ & $\begin{array}{c}0.002^{* * *} \\
(3.054)\end{array}$ & $\begin{array}{c}0.000 \\
(0.081)\end{array}$ \\
\hline Lnindex & $\begin{array}{l}0.215^{* * *} \\
(12.986)\end{array}$ & $\begin{array}{c}0.160 * * * \\
(9.277)\end{array}$ & $\begin{array}{l}0.284^{* * *} \\
(16.177)\end{array}$ & $\begin{array}{c}0.116^{* * *} \\
(7.074)\end{array}$ \\
\hline First & $\begin{array}{c}-0.013^{* * *} \\
(-4.939)\end{array}$ & $\begin{array}{c}0.001 \\
(0.184)\end{array}$ & $\begin{array}{l}-0.017^{* * *} \\
(-5.253)\end{array}$ & $\begin{array}{c}0.000 \\
(0.072)\end{array}$ \\
\hline Sloanratio & $\begin{array}{c}0.008 \\
(0.791)\end{array}$ & $\begin{array}{c}0.056^{* * *} \\
(4.630)\end{array}$ & $\begin{array}{c}0.056^{* * *} \\
(5.679)\end{array}$ & $\begin{array}{c}0.015 \\
(1.384)\end{array}$ \\
\hline Lloanratio & $\begin{array}{c}0.033^{* * *} \\
(3.819)\end{array}$ & $\begin{array}{c}0.039 * * \\
(2.168)\end{array}$ & $\begin{array}{c}0.058^{* * *} \\
(4.326)\end{array}$ & $\begin{array}{c}0.013 \\
(1.180)\end{array}$ \\
\hline Lndirector & $\begin{array}{l}-0.005 \\
(-1.215)\end{array}$ & $\begin{array}{c}-0.011^{* * *} \\
(-3.309)\end{array}$ & $\begin{array}{l}-0.010^{* *} \\
(-2.871)\end{array}$ & $\begin{array}{l}-0.002 \\
(-0.569)\end{array}$ \\
\hline Cashratio & $\begin{array}{l}0.135^{* * *} \\
(11.803)\end{array}$ & $\begin{array}{c}0.071^{* * *} \\
(4.897)\end{array}$ & $\begin{array}{l}0.146^{* * *} \\
(14.544)\end{array}$ & $\begin{array}{c}0.078^{* * *} \\
(5.433)\end{array}$ \\
\hline Profit & $\begin{array}{l}0.230^{* * *} \\
(19.814)\end{array}$ & $\begin{array}{l}0.336^{* * *} \\
(20.895)\end{array}$ & $\begin{array}{l}0.258^{* * *} \\
(16.437)\end{array}$ & $\begin{array}{l}0.287^{* * *} \\
(19.845)\end{array}$ \\
\hline Constant & $\begin{array}{l}-1.204^{* * *} \\
(-14.167)\end{array}$ & $\begin{array}{c}-0.914^{* * *} \\
(-9.676)\end{array}$ & $\begin{array}{l}-1.618^{* * *} \\
(-14.409)\end{array}$ & $\begin{array}{c}-0.646^{* * *} \\
(-6.423)\end{array}$ \\
\hline Industry & control & control & control & control \\
\hline Province & control & control & control & control \\
\hline$R$-squared & 0.555 & 0.582 & 0.444 & 0.575 \\
\hline Number of groups & 15 & 15 & 15 & 15 \\
\hline $\begin{array}{l}\text { Permutation } \\
\text { test(p-value) }\end{array}$ & 0.050 & 0.050 & 0.000 & 0.000 \\
\hline
\end{tabular}

Notes: All regressions in this table employ the cross-sectional method introduced by Fama-MacBeth (1973), and the sample period is from 2003 to 2017. The dependent variable is $S G R_{t}$, Soe equals 1 if firms are state-owned, and 0 otherwise, High-index means above-median Lnindex group and Low-index proxy for below-median Lnindex group, Lnindex is the nature log of internal control quality index. $T$ statistics are in parentheses. ${ }^{*}, * *$, and ${ }^{* * *}$ represent statistical significance at the $10 \%, 5 \%$, and $1 \%$ levels, respectively. 
To verify Hypothesis 3, we conduct regression tests on each of the samples of high-quality and low-quality enterprises, we partition the samples according to the median of internal control quality index; above the median is classified as the high-quality group, while samples below the median are classified as the low-quality group. The regression results are shown in Columns (3) and (4) in Table 4 . The coefficient on each TC is significantly positive at the $1 \%$ level, it indicates that trade credit has a significant positive impact on the sustainable growth of enterprises for both high-quality and low-quality group. Further, the estimated coefficient suggests that a one standard deviation increase in TC corresponds to a $1.63 \%(0.12 \times 0.136)$ increase in SGR for high-quality firms and a $0.83 \%(0.12 \times 0.0 .069)$ increase in $S G R$ for low-quality firms. Consistent with our expectation that trade credit functioned greatly in the sustainable growth of firms when firms with higher corporate governance level, especially higher internal control ability, the coefficient on TC is $97.1 \%$ greater than that of low-quality firms. Further, the permutation test shows that the coefficient on TC is significantly different between high-quality group and low-quality group, with a p-value below 0.01 . This supports our prediction, and is in line with previous studies that indicated effective internal control systems with the function of enhancing the corporate governance and reducing the corporate risk-taking and idiosyncratic risk [38,39] play a role in enhance firm value and performance [40], and shows that compared with the low-quality group, trade credit financing contributes more to the sustainable growth of enterprises with higher internal control ability. This is consistent with our Hypothesis 3.

The paper conducts grouping regression testing in light of the credit market development index and financial competition level in the place where the enterprise is located, and the results are as shown in Table 5. Columns (1) and (2) in Table 5 are the regression tests results for subsample with above-median and below-median credit market development index respectively. As expected, the results indicate that coefficient on TC is more positive for the subsample with below-median Creditmarket than for subsample with above-median Creditmarket. Specifically, we find that a one standard deviation increase in TC is associated with a $1.26 \%(0.12 \times 0.105)$ increase in SGR for above-median group and a $1.43 \%(0.12 \times 0.119)$ increase in SGR for below-median group, and specifically the coefficient on TC is relatively $10.9 \%$ greater than that of firms located in regions with much developed credit markets, which indicates that, in general, for regions with less developed credit markets, sustainable growth of a firm relies more on trade credit. To further prove the difference, we use an alternative measure, which is the financial competition level to proxy the financial market development degree. Columns (3) and (4) in Table 5 are respectively the regression tests results for above-median Bankcomp and below-median Bankcomp. Consistent with the analysis above, the results suggest that the financial competition level plays a significant role in promoting the sustainable growth of a firm, both for enterprises whose financial competition level is stronger and weaker than the median competition level of all provinces. By contrast, in terms of enterprises located in regions with weaker competition level, the coefficient on TC is relatively $9.3 \%$ greater than that of firms located in regions with stronger competition levels, and with a $p$-value of less than 10 percent respectively based on the Permutation test, shows that both the differences are statistically significant. This finding also provides some proof for previous research that firm growth is closely related to the development of the credit markets [41], enterprises in areas with less developed credit markets are more vulnerable to facing credit constraints and more dependent on trade credit financing $[3,10]$, thus trade credit contributed more greatly to the sustainable growth of a firm. 
Table 5. Regression of Sustainable growth of a firm on Trade credit: Grouping according to the level of financial market.

\begin{tabular}{|c|c|c|c|c|}
\hline Variables & $\begin{array}{c}\text { (1) } \\
\text { High-TCmarket }\end{array}$ & $\begin{array}{c}\text { (2) } \\
\text { Low-TCmarket }\end{array}$ & $\begin{array}{c}\text { (3) } \\
\text { High-Market }\end{array}$ & $\begin{array}{c}(4) \\
\text { Low-Market }\end{array}$ \\
\hline TC & $\begin{array}{l}0.105^{* * *} \\
(10.851)\end{array}$ & $\begin{array}{l}0.119^{* * *} \\
(11.875)\end{array}$ & $\begin{array}{l}0.108^{* * *} \\
(13.617)\end{array}$ & $\begin{array}{c}0.117^{* * *} \\
(8.995)\end{array}$ \\
\hline Lnasset & $\begin{array}{c}-0.010^{* * * *} \\
(-5.066)\end{array}$ & $\begin{array}{l}-0.012 * * * \\
(-5.290)\end{array}$ & $\begin{array}{l}-0.012^{* * * *} \\
(-6.525)\end{array}$ & $\begin{array}{c}-0.010^{* * * *} \\
(-5.131)\end{array}$ \\
\hline Lnage & $\begin{array}{l}-0.002 \\
(-1.282)\end{array}$ & $\begin{array}{c}0.002 \\
(0.893)\end{array}$ & $\begin{array}{c}-0.001 \\
(-0.570)\end{array}$ & $\begin{array}{c}0.003 \\
(1.587)\end{array}$ \\
\hline Fs & $\begin{array}{c}-0.004^{* * *} \\
(-7.377)\end{array}$ & $\begin{array}{l}-0.002^{* *} \\
(-3.127)\end{array}$ & $\begin{array}{c}-0.005^{* * *} \\
(-5.884)\end{array}$ & $\begin{array}{c}-0.003^{* * * *} \\
(-5.611)\end{array}$ \\
\hline Interfund & $\begin{array}{c}0.100^{* * * *} \\
(4.691)\end{array}$ & $\begin{array}{c}0.101^{* * *} \\
(4.784)\end{array}$ & $\begin{array}{c}0.102 * * * \\
(4.875)\end{array}$ & $\begin{array}{c}0.103^{* * *} \\
(4.683)\end{array}$ \\
\hline Currentratio & $\begin{array}{l}0.002 * * \\
(3.167)\end{array}$ & $\begin{array}{l}-0.000 \\
(-0.017)\end{array}$ & $\begin{array}{l}0.003^{* *} \\
(2.649)\end{array}$ & $\begin{array}{c}0.001 \\
(1.337)\end{array}$ \\
\hline Lnindex & $\begin{array}{l}0.215^{* * *} \\
(15.445)\end{array}$ & $\begin{array}{l}0.222 * * * \\
(10.775)\end{array}$ & $\begin{array}{l}0.208^{* * *} \\
(13.905)\end{array}$ & $\begin{array}{l}0.231^{* * *} \\
(11.749)\end{array}$ \\
\hline First & $\begin{array}{c}-0.014^{* * * *} \\
(-3.409)\end{array}$ & $\begin{array}{c}-0.008 \\
(-1.352)\end{array}$ & $\begin{array}{l}-0.011 \text { * } \\
(-1.846)\end{array}$ & $\begin{array}{l}-0.012 * * \\
(-2.489)\end{array}$ \\
\hline Sloanratio & $\begin{array}{l}0.034^{* *} \\
(2.967)\end{array}$ & $\begin{array}{l}0.044^{* *} \\
(2.985)\end{array}$ & $\begin{array}{l}0.035^{* *} \\
(2.869)\end{array}$ & $\begin{array}{c}0.043^{* * *} \\
(3.358)\end{array}$ \\
\hline Lloanratio & $\begin{array}{l}0.039 * * \\
(2.470)\end{array}$ & $\begin{array}{c}0.050^{* * *} \\
(3.663)\end{array}$ & $\begin{array}{l}0.036^{* *} \\
(2.956)\end{array}$ & $\begin{array}{l}0.039 * * \\
(3.039)\end{array}$ \\
\hline Lndirector & $\begin{array}{l}-0.009 * * \\
(-2.701)\end{array}$ & $\begin{array}{l}-0.010 \\
-1.627)\end{array}$ & $\begin{array}{l}-0.005 \\
(-1.473)\end{array}$ & $\begin{array}{l}-0.012 \\
(-1.813)\end{array}$ \\
\hline Cashratio & $\begin{array}{l}0.091^{* * *} \\
(11.025)\end{array}$ & $\begin{array}{c}0.119^{* * * *} \\
(6.875)\end{array}$ & $\begin{array}{l}0.111^{* * * *} \\
(14.538)\end{array}$ & $\begin{array}{l}0.096^{* * *} \\
(7.222)\end{array}$ \\
\hline Profit & $\begin{array}{l}0.262 * * * \\
(14.632)\end{array}$ & $\begin{array}{l}0.241^{* * *} \\
(16.566)\end{array}$ & $\begin{array}{l}0.243^{* * * *} \\
(20.759)\end{array}$ & $\begin{array}{l}0.251^{* * *} \\
(12.623)\end{array}$ \\
\hline Constant & $\begin{array}{l}-1.190^{* * *} \\
(-11.268)\end{array}$ & $\begin{array}{l}-1.179^{* * *} \\
(-11.258)\end{array}$ & $\begin{array}{l}-1.098^{* * *} \\
(-10.957)\end{array}$ & $\begin{array}{l}-1.288^{* * *} \\
(-11.309)\end{array}$ \\
\hline $\begin{array}{l}\text { Industry } \\
\text { Province }\end{array}$ & $\begin{array}{l}\text { control } \\
\text { control }\end{array}$ & $\begin{array}{l}\text { control } \\
\text { control }\end{array}$ & $\begin{array}{l}\text { control } \\
\text { control }\end{array}$ & $\begin{array}{l}\text { control } \\
\text { control }\end{array}$ \\
\hline Observations & 5149 & 4745 & 5569 & 4325 \\
\hline$R$-squared & 0.546 & 0.574 & 0.538 & 0.581 \\
\hline Number of groups & 10 & 10 & 10 & 10 \\
\hline Permutation test(p-value) & 0.080 & 0.080 & 0.070 & 0.070 \\
\hline
\end{tabular}

Notes: All regressions in this table employ the cross-sectional method introduced by Fama-MacBeth (1973), and the sample period is from 2003 to 2017. The dependent variable is $S G R_{t}$. High-TCmarket means above-median trade credit market developmental level group and Low-TCmarket proxy for below-median trade credit market developmental level group. High-market means above-median level of financial competition group and Low-market proxy for below-median level of financial competition group. T statistics are in parentheses. ${ }^{*}, * *$, and ${ }^{* * *}$ represent statistical significance at the $10 \%, 5 \%$, and $1 \%$ levels, respectively.

\subsection{Endogeneity Test}

Although the article alleviates the endogenous problem by lagging the explanatory variables, there is still a possibility that suppliers can predict the sustainable growth ability of enterprises, and thus determine the current level of trade credit provided to customers. Therefore, there is a reverse causal relationship between trade credit and firm future sustainable growth. In order to address the concern, we use a two-stage instrumental-variable regression model to alleviate the concerns with model misspecification in the ordinary least squares. We use social trust to instrument trade credit, as an informal system, social trust is reflected in its complementarity or substitution with market-based exchange and distribution system [48]. Suppliers tend to hold a positive expectation of the transaction when located in environment with a higher level of social trust, and they believe that the trade credit investment can be recovered in time, so they are willing to provide trade credit financing. However, in regions with lower level of social trust, suppliers face more risks and will be less willing to provide trade credit. The findings show that firms with socially responsibility and firms located in regions with higher social trust use more trade credit $[13,49]$. Therefore, we conjecture that social trust is strongly 
relates to trade credit. In addition, the level of social trust in a region shouldn't be directly associated with sustainable growth of firm, therefore meeting the essential requirements of the instruments. We use two different measures to proxy for social trust, the first measure, Trust, directly estimates the nature logarithm of the level of social trust and is based on data from China Comprehensive Social Survey (CGSS) similar to the World Bank Survey. The second measure that we use is Business, the nature logarithm of the number of different chambers of commerce, since chamber of commerce, as an autonomous group of businessmen, can not only provide a place for members to communicate, reduce information asymmetry and transaction costs, but also effectively increase trust among members.

Results are showed in Columns (1), (3) and (5) of Table 6, which suggest that the instruments are valid and appropriate in the first-stage regression. Specifically, our instruments (Trust and Business) are significantly $(p<0.01)$ and have a positive correlation with their respective endogenous variable, trade credit. Besides, with an F-statistic of 33.442 (34.211, 34.442) reported in Columns (1), (3) and (5) in the weak instrument test, the results indicate that the instruments we use are strong. The second-stage regression results are reported in Columns (2), (4) and (6), which show that after accounting for the endogenous relationship, the relation between trade credit and sustainable growth rate remains robust. For instance, the estimated coefficients (and $p$ values) of trade credit are $0.169(p<0.1)$ and 0.211 $(p<0.05)$ for the respectively instrumental variable, namely trust and business. Moreover the estimated coefficients (and $p$ value) of trade credit is $0.183(p<0.01)$ for both trust and business measures of social capital, and also passed the overidentification test ( $p$ value is 0.84 , indicating that all the instrumental variables are exogenous). The results, overall, indicate that the relationship between trade credit and sustainable growth of firms is not driven by the endogeneity problem. Hence, strongly support our main findings that the more use of trade credit tends to higher sustainable growth of firms.

Table 6. The two-stage least square (2SLS) estimation results.

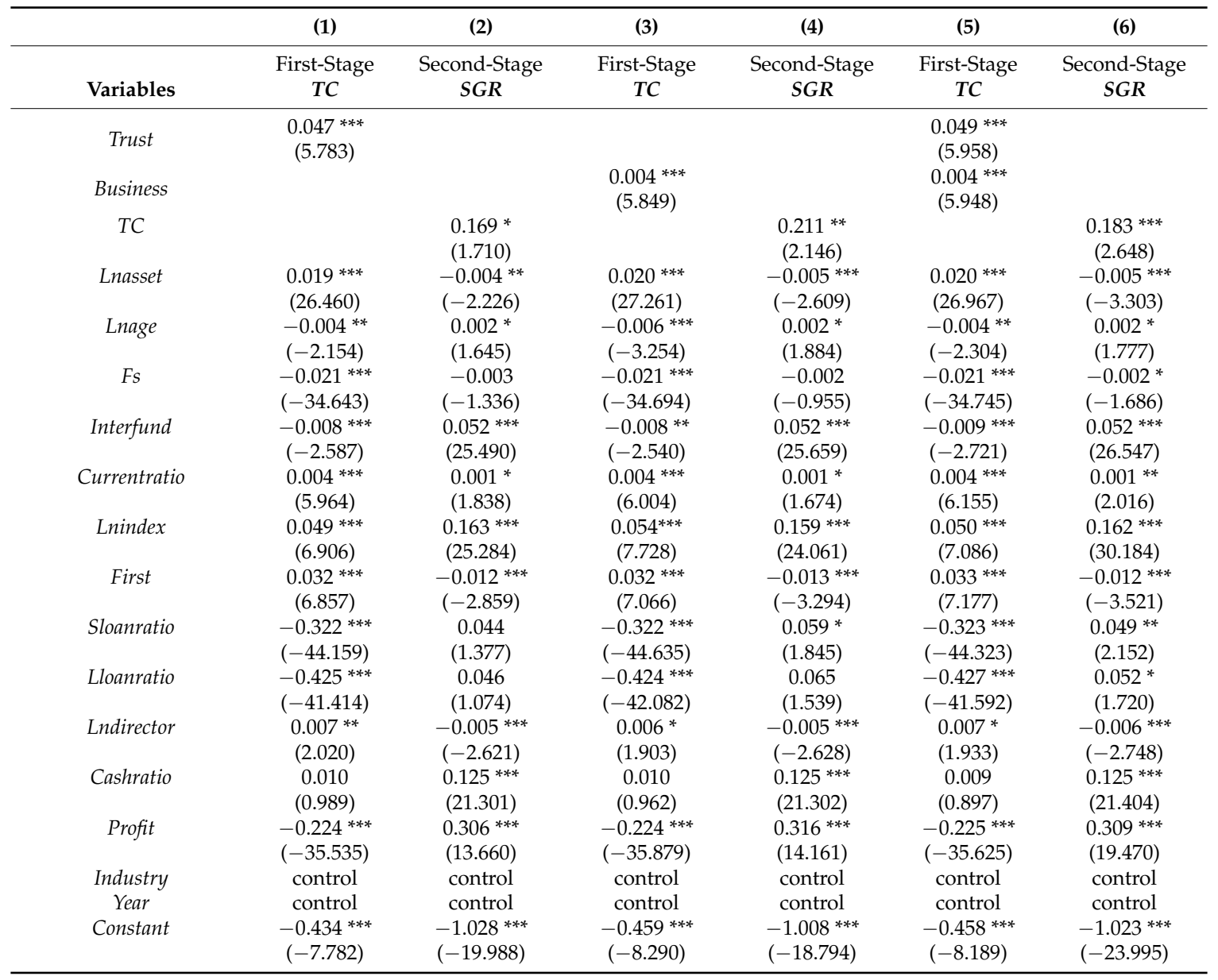


Table 6. Cont.

\begin{tabular}{|c|c|c|c|c|c|c|}
\hline & (1) & (2) & (3) & (4) & (5) & (6) \\
\hline$R$-squared & 0.439 & 0.484 & 0.436 & 0.475 & 0.440 & 0.482 \\
\hline Weak identification test & 33.442 & & 34.211 & & \multirow{2}{*}{\multicolumn{2}{|c|}{$\begin{array}{c}34.442 \\
\text { Sargan (score) } \operatorname{chi} 2(1)=0.039 \\
(p=0.84)\end{array}$}} \\
\hline Overidentification test & & & & & & \\
\hline
\end{tabular}

Notes: The instruments for trade credit are Business and Trust, Trust is province-year level of social trust, and Business is province level of numbers of different chamber of commerce. The sample period is from 2003 to 2017 . T statistics are in parentheses. ${ }^{*}, * *$, and ${ }^{* *}$ represent statistical significance at the $10 \%, 5 \%$, and $1 \%$ levels, respectively.

\subsection{Robustness Tests}

We used Higgins' model [8] as an alternative measure of the sustainable growth rate. The results are reported in Table 7, and consistent with our prediction that trade credit is positively associated with sustainable growth of firm in the current year and next three years from Panel A, Panel B shows that trade credit has more effects on sustainable growth of a firm when the firm is non-stated-owned or of a higher level of internal control quality. Panel $C$ suggests the results are robust when we use Business to instrument for trade credit. In addition, we estimate the effect of trade credit on sustainable growth of a firm, based on OLS regression, by controlling for industry, province and year effects. The results are reported in Table 8; Panel A shows that trade credit is significantly related to sustainable growth of firm, Panel B and Panel C show that heterogeneous effects of trade credit on sustainable growth of firm among different groups of firms are still consistent with the above, namely trade credit contributes more to sustainable growth of a firm when the firm is non-state-owned or of a higher level of internal control quality, besides, sustainable growth of firm rely more on trade credit in a region with a higher level of financial development. Thus, it can be concluded that the empirical results in this paper are robust.

Table 7. Robustness test: Alternative measure of sustainable growth of firm.

\begin{tabular}{|c|c|c|c|c|}
\hline \multicolumn{5}{|c|}{ Panel A: Regression of Sustainable growth of firm on Trade credit. } \\
\hline \multirow[b]{2}{*}{ Variables } & (1) & (2) & (3) & (4) \\
\hline & $S G R 1_{t}$ & $S G R 1_{t+1}$ & $S G R 1_{t+2}$ & $S G R 1_{t+3}$ \\
\hline \multirow[t]{2}{*}{$T C$} & $0.109 * * *$ & $0.124 * * *$ & $0.103^{* * *}$ & $0.094^{* * *}$ \\
\hline & (15.138) & (10.679) & (9.853) & $(5.746)$ \\
\hline \multirow[t]{2}{*}{ Lnasset } & $-0.006^{* * *}$ & $-0.005^{* * *}$ & $-0.006^{* * *}$ & $-0.007^{* *}$ \\
\hline & $(-3.914)$ & $(-3.014)$ & $(-3.085)$ & $(-2.893)$ \\
\hline \multirow[t]{2}{*}{ Lnage } & 0.001 & -0.000 & $0.002 *$ & 0.003 \\
\hline & $(1.084)$ & $(-0.104)$ & $(1.917)$ & $(1.405)$ \\
\hline \multirow[t]{2}{*}{ Fs } & $-0.004^{* * *}$ & $-0.003^{* * *}$ & $-0.004^{* * *}$ & $-0.003^{* * *}$ \\
\hline & $(-18.118)$ & $(-7.316)$ & $(-4.870)$ & $(-4.771)$ \\
\hline \multirow[t]{2}{*}{ Interfund } & $0.174^{* * *}$ & $0.060^{* * *}$ & $0.048^{* * *}$ & 0.021 \\
\hline & (12.007) & $(5.300)$ & $(4.033)$ & $(1.518)$ \\
\hline \multirow[t]{2}{*}{ Currentratio } & $0.002^{* * *}$ & $0.002^{* * *}$ & $0.002^{* *}$ & $0.002^{* * *}$ \\
\hline & $(4.278)$ & $(3.380)$ & $(2.940)$ & $(3.727)$ \\
\hline \multirow[t]{2}{*}{ Lnindex } & $0.175^{* * *}$ & $0.106^{* * *}$ & $0.087^{* * *}$ & $0.077^{* * *}$ \\
\hline & $(13.051)$ & $(7.393)$ & $(5.564)$ & $(3.653)$ \\
\hline \multirow[t]{2}{*}{ First } & $-0.009^{* * *}$ & -0.009 & -0.005 & -0.006 \\
\hline & $(-3.350)$ & $(-1.643)$ & $(-0.721)$ & $(-0.822)$ \\
\hline \multirow[t]{2}{*}{ Sloanratio } & $0.037^{* * *}$ & $0.025^{* *}$ & 0.016 & 0.019 \\
\hline & $(4.063)$ & $(2.649)$ & (1.422) & (1.577) \\
\hline \multirow[t]{2}{*}{ Lloanratio } & $0.030^{* * *}$ & $0.048^{* * *}$ & $0.038^{* *}$ & 0.038 * \\
\hline & (3.919) & $(4.019)$ & $(2.742)$ & (1.958) \\
\hline
\end{tabular}


Table 7. Cont.

\begin{tabular}{|c|c|c|c|c|}
\hline \multicolumn{5}{|c|}{ Panel A: Regression of Sustainable growth of firm on Trade credit. } \\
\hline \multirow[b]{2}{*}{ Variables } & (1) & (2) & (3) & (4) \\
\hline & $S G R 1_{t}$ & $S G R 1_{t+1}$ & $S G R 1_{t+2}$ & $S G R 1_{t+3}$ \\
\hline \multirow[t]{2}{*}{ Lndirector } & $-0.009 * * *$ & $-0.008 *$ & -0.005 & -0.006 \\
\hline & $(-4.062)$ & $(-2.049)$ & $(-1.235)$ & $(-1.277)$ \\
\hline \multirow[t]{2}{*}{ Cashratio } & $0.114^{* * *}$ & $0.166^{* * *}$ & $0.147^{* * *}$ & $0.129 * * *$ \\
\hline & $(14.039)$ & $(15.701)$ & $(11.324)$ & $(10.728)$ \\
\hline \multirow[t]{2}{*}{ Profit } & $0.261^{* * *}$ & $0.173^{* * *}$ & $0.140^{* * *}$ & $0.109^{* * *}$ \\
\hline & $(18.501)$ & $(16.418)$ & $(13.430)$ & $(7.904)$ \\
\hline \multirow[t]{2}{*}{ Constant } & $-0.999 * * *$ & $-0.544^{* * *}$ & $-0.399^{* * *}$ & $-0.330 * * *$ \\
\hline & $(-15.007)$ & $(-6.483)$ & $(-5.786)$ & $(-3.406)$ \\
\hline Industry & control & control & control & control \\
\hline Province & control & control & control & control \\
\hline Observations & 20,089 & 17,539 & 15,358 & 13,430 \\
\hline$R$-squared & 0.603 & 0.251 & 0.188 & 0.151 \\
\hline Number of groups & 15 & 14 & 13 & 12 \\
\hline \multicolumn{5}{|c|}{ Panel B: Regression of Sustainable growth of firm on Trade credit: grouping according to internal characteristics. } \\
\hline & (1) & (2) & (3) & (4) \\
\hline Variables & Soe $=1$ & Soe $=0$ & High-index & Low-index \\
\hline \multirow[t]{2}{*}{ TC } & $0.096^{* * *}$ & $0.130 * * *$ & $0.139 * * *$ & $0.067^{* * *}$ \\
\hline & $(10.684)$ & $(10.875)$ & $(15.289)$ & $(8.260)$ \\
\hline \multirow[t]{2}{*}{ Lnasset } & $-0.008^{* * *}$ & -0.005 & $-0.011^{* * *}$ & $-0.005^{* * *}$ \\
\hline & $(-5.860)$ & $(-1.756)$ & $(-5.206)$ & $(-3.937)$ \\
\hline \multirow[t]{2}{*}{ Lnage } & $0.006^{* * *}$ & 0.001 & 0.002 & 0.002 \\
\hline & $(3.048)$ & $(0.445)$ & $(1.581)$ & (1.167) \\
\hline \multirow[t]{2}{*}{ Fs } & $-0.005^{* * *}$ & $-0.003^{* *}$ & $-0.005^{* * *}$ & $-0.003^{* * *}$ \\
\hline & $(-7.601)$ & $(-2.848)$ & $(-8.198)$ & $(-8.805)$ \\
\hline \multirow[t]{2}{*}{ Interfund } & $0.177^{* * *}$ & $0.179^{* * *}$ & $0.176^{* * *}$ & $0.174^{* * *}$ \\
\hline & $(14.222)$ & $(8.300)$ & $(12.476)$ & $(8.540)$ \\
\hline \multirow[t]{2}{*}{ Currentratio } & $0.003^{* * *}$ & 0.001 & $0.003^{* * *}$ & 0.000 \\
\hline & $(5.301)$ & $(1.047)$ & $(3.539)$ & $(0.706)$ \\
\hline \multirow[t]{2}{*}{ Lnindex } & $0.202^{* * *}$ & $0.147^{* * *}$ & $0.278^{* * *}$ & $0.098^{* * *}$ \\
\hline & $(13.570)$ & $(9.444)$ & $(15.275)$ & $(7.220)$ \\
\hline \multirow[t]{2}{*}{ First } & $-0.010^{* * *}$ & 0.002 & $-0.014^{* * *}$ & 0.002 \\
\hline & $(-3.691)$ & $(0.495)$ & $(-4.310)$ & $(0.572)$ \\
\hline \multirow[t]{2}{*}{ Sloanratio } & 0.012 & $0.062^{* * *}$ & $0.061^{* * *}$ & 0.019 \\
\hline & (1.097) & $(5.072)$ & $(6.158)$ & (1.668) \\
\hline \multirow[t]{2}{*}{ Lloanratio } & $0.033^{* * *}$ & $0.037^{*}$ & $0.058^{* * *}$ & 0.010 \\
\hline & $(3.789)$ & $(2.079)$ & $(4.408)$ & $(0.850)$ \\
\hline \multirow[t]{2}{*}{ Lndirector } & $-0.007^{* *}$ & $-0.011^{* * *}$ & $-0.012^{* * *}$ & -0.003 \\
\hline & $(-2.319)$ & $(-3.198)$ & $(-3.491)$ & $(-0.786)$ \\
\hline \multirow[t]{2}{*}{ Cashratio } & $0.136^{* * *}$ & $0.072^{* * *}$ & $0.143^{* * *}$ & $0.082^{* * *}$ \\
\hline & (12.310) & $(4.568)$ & $(14.031)$ & $(5.507)$ \\
\hline Profit & $0.221^{* * *}$ & $0.332^{* * *}$ & $0.258^{* * *}$ & $0.284^{* * *}$ \\
\hline & (19.180) & (19.212) & $(15.530)$ & (17.726) \\
\hline Constant & $-1.147^{* * *}$ & $-0.841^{* * *}$ & $-1.607^{* * *}$ & $-0.545^{* * *}$ \\
\hline & $(-14.606)$ & $(-9.626)$ & $(-13.772)$ & $(-6.486)$ \\
\hline Industry & control & control & control & control \\
\hline Province & control & control & control & control \\
\hline Observations & 9477 & 10,425 & 10,050 & 10,039 \\
\hline$R$-squared & 0.619 & 0.655 & 0.547 & 0.625 \\
\hline Number of groups & 15 & 15 & 15 & 15 \\
\hline $\begin{array}{l}\text { Permutation test } \\
\quad(p \text {-value })\end{array}$ & 0.007 & 0.007 & 0.000 & 0.000 \\
\hline
\end{tabular}


Table 7. Cont.

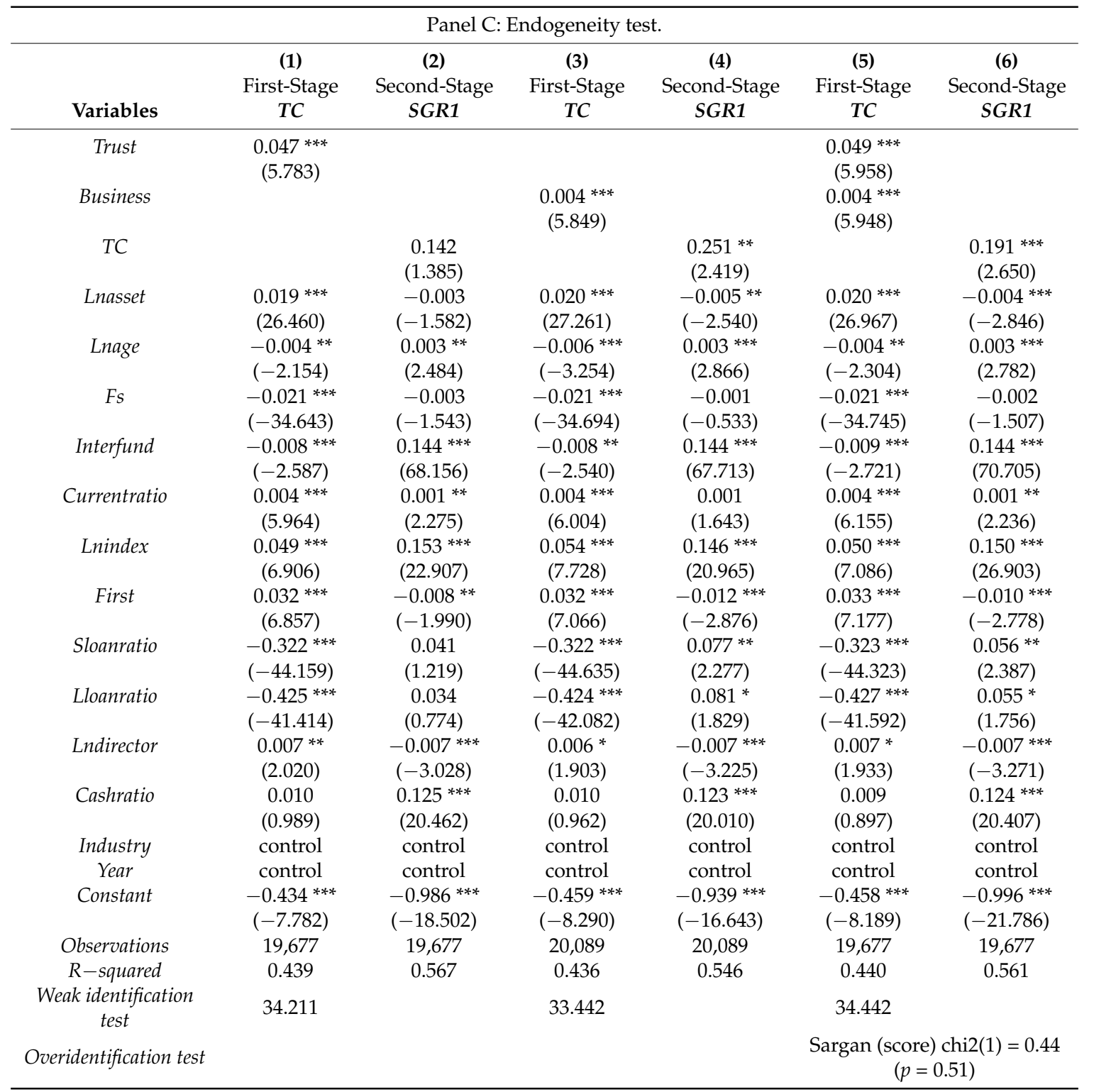

Notes: regressions in Panel A and Panel B use the cross-sectional method introduced by Fama-MacBeth (1973), and the sample period is from 2003 to 2017. The dependent variable is SGR1. The instruments for trade credit are Business and Trust in Panel C, Trust is province-year level of social trust, Business is province level of numbers of different chamber of commerce. T statistics are in parentheses. ${ }^{*}, * *$, and ${ }^{* * *}$ represent statistical significance at the $10 \%, 5 \%$, and $1 \%$ levels, respectively.

Table 8. Robustness test: OLS regression results.

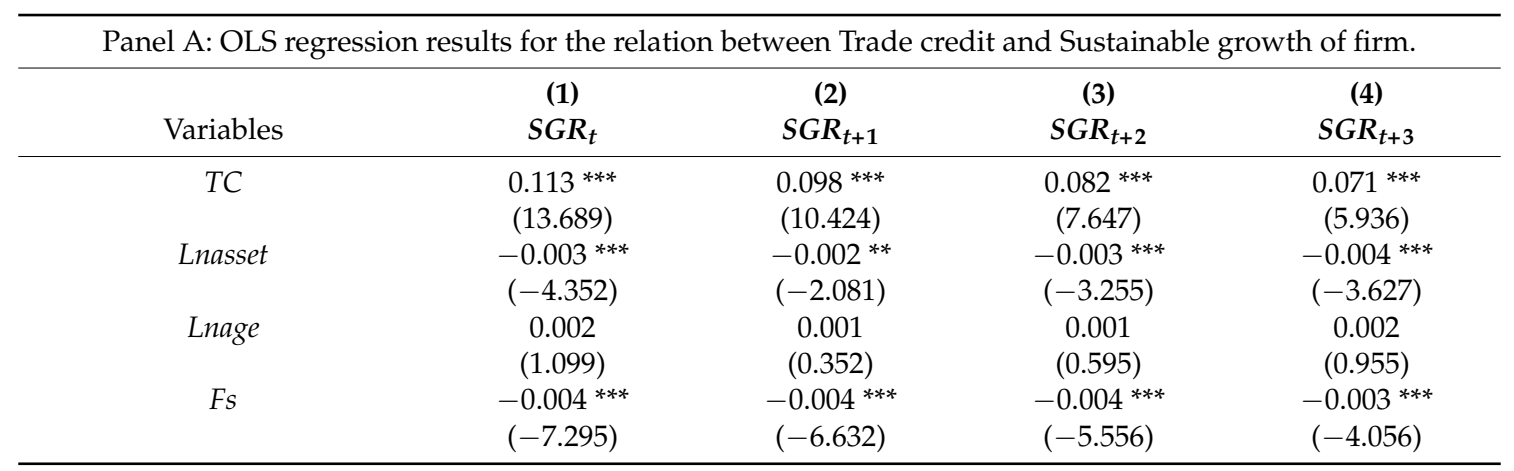


Table 8. Cont.

\begin{tabular}{|c|c|c|c|c|}
\hline \multicolumn{5}{|c|}{ Panel A: OLS regression results for the relation between Trade credit and Sustainable growth of firm. } \\
\hline \multirow[b]{2}{*}{ Variables } & \multirow{2}{*}{$\begin{array}{c}(\mathbf{1}) \\
S G R_{t}\end{array}$} & \multirow{2}{*}{$\begin{array}{c}(2) \\
S G R_{t+1}\end{array}$} & \multirow{2}{*}{$\begin{array}{c}(3) \\
S G R_{t+2}\end{array}$} & \multirow{2}{*}{$\begin{array}{c}(4) \\
S G R_{t+3}\end{array}$} \\
\hline & & & & \\
\hline Interfund & $0.051^{* * *}$ & $0.035^{* * *}$ & $0.026^{* * *}$ & $0.012 * * *$ \\
\hline & $(18.162)$ & $(12.324)$ & $(7.835)$ & $(3.086)$ \\
\hline \multirow[t]{2}{*}{ Currentratio } & $0.001 * *$ & $0.002 * * *$ & $0.002 * * *$ & $0.002 * * *$ \\
\hline & $(2.053)$ & $(3.383)$ & $(3.189)$ & $(2.914)$ \\
\hline \multirow[t]{2}{*}{ Lnindex } & $0.164^{* * *}$ & $0.087^{* * *}$ & $0.075^{* * *}$ & $0.071^{* * *}$ \\
\hline & $(26.183)$ & $(12.096)$ & $(8.778)$ & $(7.116)$ \\
\hline \multirow[t]{2}{*}{ First } & $-0.010 * *$ & -0.006 & -0.002 & 0.000 \\
\hline & $(-2.154)$ & $(-1.133)$ & $(-0.247)$ & $(0.062)$ \\
\hline \multirow[t]{2}{*}{ Sloanratio } & $0.027^{* * *}$ & -0.002 & -0.004 & 0.003 \\
\hline & $(3.834)$ & $(-0.262)$ & $(-0.403)$ & $(0.270)$ \\
\hline \multirow[t]{2}{*}{ Lloanratio } & $0.024^{* *}$ & 0.018 & 0.017 & 0.019 \\
\hline & (2.147) & $(1.474)$ & (1.258) & (1.334) \\
\hline \multirow[t]{2}{*}{ Lndirector } & -0.004 & -0.004 & -0.003 & -0.003 \\
\hline & $(-1.359)$ & $(-1.217)$ & $(-0.663)$ & $(-0.588)$ \\
\hline \multirow[t]{2}{*}{ Cashratio } & $0.126^{* * *}$ & $0.166^{* * *}$ & $0.151^{* * *}$ & $0.134 * * *$ \\
\hline & $(13.394)$ & (15.107) & $(12.520)$ & $(10.343)$ \\
\hline \multirow[t]{2}{*}{ Profit } & $0.294^{* * *}$ & $0.165 * * *$ & $0.125^{* * *}$ & $0.091^{* * *}$ \\
\hline & $(30.067)$ & $(20.238)$ & $(14.416)$ & (9.175) \\
\hline \multirow[t]{2}{*}{ Constant } & $-0.991^{* * *}$ & $-0.514^{* * *}$ & $-0.351^{* * *}$ & $-0.282^{* * *}$ \\
\hline & $(-21.414)$ & $(-10.141)$ & $(-5.629)$ & $(-3.983)$ \\
\hline Industry & control & control & control & control \\
\hline Province & control & control & control & control \\
\hline Year & control & control & control & control \\
\hline Observations & 20,089 & 17,539 & 15,358 & 13,430 \\
\hline$R$-squared & 0.492 & 0.239 & 0.171 & 0.120 \\
\hline
\end{tabular}

\begin{tabular}{|c|c|c|c|c|}
\hline Variables & $\begin{array}{c}(1) \\
\text { Soe }=1\end{array}$ & $\begin{array}{c}(2) \\
\text { Soe }=0\end{array}$ & $\begin{array}{c}\text { (3) } \\
\text { High-index }\end{array}$ & $\begin{array}{c}(4) \\
\text { Low-index }\end{array}$ \\
\hline$T C$ & $\begin{array}{l}0.101^{* * *} \\
(17.783)\end{array}$ & $\begin{array}{l}0.116^{* * *} \\
(19.562)\end{array}$ & $\begin{array}{l}0.143^{* * *} \\
(23.814)\end{array}$ & $\begin{array}{l}0.072 * * * \\
(13.416)\end{array}$ \\
\hline Lnasset & $\begin{array}{l}0.007^{* * *} \\
(-11.679)\end{array}$ & $\begin{array}{c}0.002^{* * *} \\
(2.785)\end{array}$ & $\begin{array}{c}-0.006^{* * *} \\
(-8.685)\end{array}$ & $\begin{array}{c}-0.004^{* * *} \\
(-7.289)\end{array}$ \\
\hline Lnage & $\begin{array}{c}0.003 \\
(1.443)\end{array}$ & $\begin{array}{l}-0.000 \\
(-0.060)\end{array}$ & $\begin{array}{c}0.002 \\
(1.449)\end{array}$ & $\begin{array}{c}0.001 \\
(1.128)\end{array}$ \\
\hline Fs & $\begin{array}{c}-0.005^{* * *} \\
(-9.829)\end{array}$ & $\begin{array}{c}-0.002 * * * \\
(-5.504)\end{array}$ & $\begin{array}{l}-0.006^{* * *} \\
(-10.430)\end{array}$ & $\begin{array}{c}-0.003^{* * *} \\
(-6.562)\end{array}$ \\
\hline Interfund & $\begin{array}{l}0.069 * * * \\
(23.163)\end{array}$ & $\begin{array}{l}0.033^{* * *} \\
(14.247)\end{array}$ & $\begin{array}{l}0.039 * * * \\
(14.790)\end{array}$ & $\begin{array}{l}0.060^{* * *} \\
(23.834)\end{array}$ \\
\hline Currentratio & $\begin{array}{c}0.003 * * * \\
(4.568)\end{array}$ & $\begin{array}{l}-0.000 \\
(-0.345)\end{array}$ & $\begin{array}{c}0.003 * * * \\
(4.404)\end{array}$ & $\begin{array}{l}-0.000 \\
(-0.525)\end{array}$ \\
\hline Lnindex & $\begin{array}{l}0.191^{* * *} \\
(32.672)\end{array}$ & $\begin{array}{l}0.143^{* * *} \\
(25.300)\end{array}$ & $\begin{array}{l}0.235^{* * *} \\
(23.317)\end{array}$ & $\begin{array}{l}0.113^{* * *} \\
(17.736)\end{array}$ \\
\hline First & $\begin{array}{l}-0.013^{* * *} \\
(-3.296)\end{array}$ & $\begin{array}{l}-0.003 \\
(-0.715)\end{array}$ & $\begin{array}{l}-0.0211^{* * *} \\
(-5.290)\end{array}$ & $\begin{array}{c}0.002 \\
(0.683)\end{array}$ \\
\hline Sloanratio & $\begin{array}{c}0.005 \\
(0.774)\end{array}$ & $\begin{array}{c}0.043^{* * *} \\
(7.095)\end{array}$ & $\begin{array}{c}0.057^{* * *} \\
(8.374)\end{array}$ & $\begin{array}{l}0.011 \text { ** } \\
(1.980)\end{array}$ \\
\hline Lloanratio & $\begin{array}{c}0.028 * * * \\
(3.536)\end{array}$ & $\begin{array}{c}0.016 \\
(1.571)\end{array}$ & $\begin{array}{c}0.043 * * * \\
(4.727)\end{array}$ & $\begin{array}{l}0.015^{*} \\
(1.868)\end{array}$ \\
\hline Lndirector & $\begin{array}{l}-0.005^{*} \\
(-1.906)\end{array}$ & $\begin{array}{l}-0.004 \\
(-1.411)\end{array}$ & $\begin{array}{l}-0.009^{* * * *} \\
(-3.087)\end{array}$ & $\begin{array}{c}0.000 \\
(0.111)\end{array}$ \\
\hline Cashratio & $\begin{array}{l}0.142^{* * *} \\
(16.670)\end{array}$ & $\begin{array}{l}0.101^{* * *} \\
(13.216)\end{array}$ & $\begin{array}{l}0.159 * * * \\
(18.963)\end{array}$ & $\begin{array}{l}0.091^{* * *} \\
(12.023)\end{array}$ \\
\hline Profit & $\begin{array}{l}0.259 * * * \\
(47.959)\end{array}$ & $\begin{array}{c}0.330 * * * \\
(64.467)\end{array}$ & $\begin{array}{l}0.289 * * * \\
(49.802)\end{array}$ & $\begin{array}{l}0.314^{* * *} \\
(67.970)\end{array}$ \\
\hline $\begin{array}{l}\text { Constant } \\
\text { Industry }\end{array}$ & $\begin{array}{c}-1.090^{* * *} \\
(-29.074) \\
\text { control }\end{array}$ & $\begin{array}{c}-1.040^{* * *} \\
(-16.290) \\
\text { control }\end{array}$ & $\begin{array}{c}-1.475^{* * *} \\
(-21.847) \\
\text { control }\end{array}$ & $\begin{array}{c}-0.647 * * * \\
(-12.597) \\
\text { control }\end{array}$ \\
\hline
\end{tabular}


Table 8. Cont.

\begin{tabular}{ccccc}
\hline \multicolumn{2}{c}{ Panel B: Regression of Sustainable growth of firm on } & Trade credit: & grouping & according to internal characteristics. \\
\hline Variables & $\mathbf{( 1 )}$ & $\mathbf{( 2 )}$ & $\mathbf{( 3 )}$ & $\mathbf{( 4 )}$ \\
Province & Soe $=\mathbf{1}$ & Soe $=\mathbf{0}$ & High-index & Low-index \\
Year & control & control & control & control \\
Observations & control & control & control & control \\
R-squared & 9477 & 10,425 & 10,050 & 10,039 \\
Permutation test $(p-$ value $)$ & 0.518 & 0.494 & 0.398 & 0.507 \\
\hline
\end{tabular}

Panel C: Regression of Sustainable growth of firm on Trade credit: Grouping according to the level of financial market.

\begin{tabular}{|c|c|c|c|c|}
\hline Variables & $\begin{array}{c}\text { (1) } \\
\text { High-TCmarket }\end{array}$ & $\begin{array}{c}\text { (2) } \\
\text { Low-TCmarket }\end{array}$ & $\begin{array}{c}\text { (3) } \\
\text { High-market }\end{array}$ & $\begin{array}{c}\text { (4) } \\
\text { Low-market }\end{array}$ \\
\hline$T C$ & $\begin{array}{l}0.110 * * * \\
(13.606)\end{array}$ & $\begin{array}{l}0.129 * * * \\
(14.818)\end{array}$ & $\begin{array}{l}0.112 * * * \\
(14.413)\end{array}$ & $\begin{array}{l}0.130 * * * \\
(14.245)\end{array}$ \\
\hline Lnasset & $\begin{array}{l}-0.007^{* * * *} \\
(-6.843)\end{array}$ & $\begin{array}{l}-0.012^{* * *} \\
(-12.103)\end{array}$ & $\begin{array}{l}-0.010^{* * * *} \\
(-10.560)\end{array}$ & $\begin{array}{l}-0.010^{* * * *} \\
(-8.753)\end{array}$ \\
\hline Lnage & $\begin{array}{l}-0.000 \\
(-0.190)\end{array}$ & $\begin{array}{c}0.005^{* *} \\
(2.155)\end{array}$ & $\begin{array}{c}0.001 \\
(0.529)\end{array}$ & $\begin{array}{c}0.004 \\
(1.614)\end{array}$ \\
\hline Fs & $\begin{array}{c}-0.005^{* * *} \\
(-6.822)\end{array}$ & $\begin{array}{c}-0.002 * * * \\
(-2.763)\end{array}$ & $\begin{array}{c}-0.004^{* * *} \\
(-6.239)\end{array}$ & $\begin{array}{c}-0.003^{* * *} \\
(-4.357)\end{array}$ \\
\hline Interfund & $\begin{array}{l}0.072^{* * * *} \\
(16.705)\end{array}$ & $\begin{array}{l}0.074^{* * *} \\
(16.176)\end{array}$ & $\begin{array}{l}0.075^{* * * *} \\
(17.594)\end{array}$ & $\begin{array}{l}0.072 * * * \\
(15.550)\end{array}$ \\
\hline Currentratio & $\begin{array}{c}0.002^{* * * *} \\
(2.661)\end{array}$ & $\begin{array}{c}-0.001 \\
(-1.099)\end{array}$ & $\begin{array}{l}0.002 * * \\
(2.092)\end{array}$ & $\begin{array}{c}0.000 \\
(0.401)\end{array}$ \\
\hline Lnindex & $\begin{array}{l}0.207^{* * *} \\
(24.064)\end{array}$ & $\begin{array}{l}0.218^{* * *} \\
(23.808)\end{array}$ & $\begin{array}{l}0.205^{* * *} \\
(25.040)\end{array}$ & $\begin{array}{l}0.226^{* * *} \\
(23.142)\end{array}$ \\
\hline First & $\begin{array}{l}-0.016^{* * *} \\
(-3.001)\end{array}$ & $\begin{array}{l}-0.004 \\
(-0.747)\end{array}$ & $\begin{array}{l}-0.011^{* *} \\
(-2.220)\end{array}$ & $\begin{array}{l}-0.012 * \\
(-1.896)\end{array}$ \\
\hline Sloanratio & $\begin{array}{c}0.028^{* * *} \\
(3.404)\end{array}$ & $\begin{array}{l}0.036^{* * *} \\
(3.959)\end{array}$ & $\begin{array}{c}0.028 * * * \\
(3.562)\end{array}$ & $\begin{array}{c}0.038^{* * *} \\
(3.908)\end{array}$ \\
\hline Lloanratio & $\begin{array}{c}0.036^{* * *} \\
(2.994)\end{array}$ & $\begin{array}{c}0.044^{* * *} \\
(3.799)\end{array}$ & $\begin{array}{c}0.027^{* *} \\
(2.328)\end{array}$ & $\begin{array}{c}0.043^{* * *} \\
(3.498)\end{array}$ \\
\hline Lndirector & $\begin{array}{c}-0.006 \\
(-1.523)\end{array}$ & $\begin{array}{l}-0.007^{*} \\
(-1.738)\end{array}$ & $\begin{array}{c}-0.004 \\
(-1.093)\end{array}$ & $\begin{array}{l}-0.008^{*} \\
(-1.769)\end{array}$ \\
\hline Cashratio & $\begin{array}{c}0.085^{* * *} \\
(7.904)\end{array}$ & $\begin{array}{l}0.137^{* * * *} \\
(11.472)\end{array}$ & $\begin{array}{l}0.108^{* * *} \\
(10.213)\end{array}$ & $\begin{array}{c}0.110^{* * *} \\
(8.854)\end{array}$ \\
\hline Profit & $\begin{array}{l}0.278^{* * *} \\
(33.388)\end{array}$ & $\begin{array}{l}0.257^{* * *} \\
(31.921)\end{array}$ & $\begin{array}{l}0.262^{* * *} \\
(34.913)\end{array}$ & $\begin{array}{l}0.272 * * * \\
(30.320)\end{array}$ \\
\hline Constant & $\begin{array}{l}-1.173^{* * *} \\
(-15.100)\end{array}$ & $\begin{array}{l}-1.175^{* * *} \\
(-18.947)\end{array}$ & $\begin{array}{l}-1.146^{* * *} \\
(-16.239)\end{array}$ & $\begin{array}{l}-1.279 * * * \\
(-19.818)\end{array}$ \\
\hline Industry & control & control & control & control \\
\hline Province & control & control & control & control \\
\hline Year & control & control & control & control \\
\hline Observations & 5149 & 4745 & 5569 & 4325 \\
\hline$R$-squared & 0.521 & 0.533 & 0.512 & 0.541 \\
\hline$F$ & 95.43 & 83.31 & 107.2 & 79.78 \\
\hline Permutation test(p-value) & 0.080 & 0.080 & 0.070 & 0.070 \\
\hline
\end{tabular}

Notes: All estimates in this table employ the OLS regression, and the sample period is from 2003 to 2017. The dependent variable is SGR. In Panel B, Soe equals 1 if firms are state-owned, and 0 otherwise, High-index means above-median Lnindex group and Low-index proxy for below-median Lnindex group, Lnindex is the nature log of internal control quality index. In Panel C, High-TCmarket means above-median trade credit market developmental level group and Low-TCmarket proxy for below-median trade credit market developmental level group. High-market means above-median level of financial competition group and Low-market proxy for below-median level of financial competition group. $T$ statistics are in parentheses. ${ }^{*}, * *$, and ${ }^{* * *}$ represent statistical significance at the $10 \%, 5 \%$, and $1 \%$ levels, respectively.

\section{Conclusions}

Trade credit is not only one of the most commonly used methods in informal financing of enterprises, but also one of the most critical sources of short-term funds [50,51]. In developing 
counties whose financial development has been restricted, trade credit also can be used as an effective alternative mechanism of bank credit to ease the financing constraints for the enterprise. This paper, on the basis of theoretical analysis, adopting the samples of non-financial listed companies of China A-shares from 2003 to 2017, conducts an empirical analysis of the impact of trade credit application on sustainable firm growth. The results show that trade credit financing considerably accelerates the pace of Chinese enterprises' sustainable growth. In particular, for private enterprises, the effect of trade credit financing on enterprises is larger, and for firms with a higher level of internal control quality, trade credit financing contributes relatively more to the sustainable growth of a firm. The paper also further studies the impact of the development level of financial markets on stimulating the sustainable growth of a firm. The study finds that in areas with a lower development level of the credit market or lower development level of financial competition, the effect of trade credit financing on firm growth is relatively stronger. In contrast, in areas with a higher development level of financial market, trade credit makes a relatively small contribution to the sustainable growth of a firm.

The research results of the paper help to explain the vital theoretical issue of why China's private enterprises can achieve rapid and sustainable growth under the relatively lagging formal financial system. Implications from the conclusions in the paper include that, as the financial system is not perfect in such countries as China, trade credit financing is still a viable and alternative channel to solve the problem of financing difficulties for private enterprises. Enterprises, particularly private enterprises, should attach importance to trade credit financing to alleviate the financing constraint, thus promoting sustainable growth of the firm. The paper also helps to emphasize the importance of firm internal control quality, which plays a vital role in promoting sustainable growth of the firm. With the development of the financial market, as well as the boost in capital allocation efficiency in bank credit, the significance of trade credit financing to sustainable growth of firm will be weakened step by step. In the long term, a perfect financial system, including credit markets, is the essential way to resolve the financing bottleneck for sustainable growth of firms.

Author Contributions: L.H. ran regressions and wrote preliminary draft of the paper. Q.Y. analyzed literature, developed the research hypotheses, designed the research framework and reviewed the paper; S.Y. collected and analyzed the data and H.H. reviewed and edited the paper.

Funding: This research was funded by the National Science Foundation of China (71373167), Youth Fund Project of Humanities and social sciences of the Ministry of Education in China (18YJC790204), Social Science Key Project of Sichuan Province of China (SC18A006), the Soft Science Foundation Project of Sichuan Province of China (2017ZR0191) and the research fund from Sichuan University (SKSYL201822, 2018hhf-47, skqx201608, 2013SCU04A32).

Acknowledgments: This work was supported by the National Science Foundation of China (71373167), Youth Fund Project of Humanities and social sciences of the Ministry of Education in China (18YJC790204), Social Science Key Project of Sichuan Province of China (SC18A006), the Soft Science Foundation Project of Sichuan Province of China (2017ZR0191) and the research fund from Sichuan University (SKSYL201822, skqx201608, 2013SCU04A32).

Conflicts of Interest: The authors have no conflict of interest.

\section{References}

1. Fowowe, B. Access to finance and firm performance: Evidence from African countries. Rev. Dev. Financ. 2017, 7, 6-17. [CrossRef]

2. Cortina, J.J.; Ismail, S.; Schmukler, S.L. Firm financing and growth in the Arab region. Econ. Syst. 2018, 42, 361-383. [CrossRef]

3. Fisman, R.; Love, I. Trade Credit, Financial Intermediary Development, and Industry Growth. J. Financ. 2003, 58, 353-374. [CrossRef]

4. Degryse, H.; Lu, L.; Ongena, S. Informal or formal financing? Evidence on the co-funding of Chinese firms. J. Financ. Intermediat. 2016, 27, 31-50. [CrossRef]

5. Hasan, M.M.; Habib, A. Social capital and trade credit. Int. Rev. Financ. Anal. Available online: https: / / papers.ssrn.com/sol3 / papers.cfm?abstract_id=3055327 (accessed on 3 February 2019). 
6. Molina, C.A.; Preve, L.A. An Empirical Analysis of the Effect of Financial Distress on Trade Credit. Financ. Manag. 2012, 41, 187-205. [CrossRef]

7. Burkart, M.; Ellingsen, T. In-Kind Finance: A Theory of Trade Credit. Am. Econ. Rev. 2004, 94, 569-590. [CrossRef]

8. Chen, D.; Liu, M.; Ma, T.; Martin, X. Accounting Quality and Trade Credit. Account. Horiz. 2017, 31, 69-83. [CrossRef]

9. McMillan, J.; MWoodruff, C. Interfirm Relationships and Informal Credit in Vietnam. Q. J. Econ. 1999, 114, 1285-1320. [CrossRef]

10. Cull, R.; Xu, L.C.; Zhu, T. Formal finance and trade credit during China's transition. J. Financ. Intermediat. 2009, 18, 173-192. [CrossRef]

11. Hermes, N.; Kihanga, E.; Lensink, R.; Lutz, C. The determinants of trade credit use: The case of the Tanzanian rice market. Appl. Econ. 2015, 47, 3164-3174. [CrossRef]

12. Wu, W.; Rui, O.M.; Wu, C. Trade credit, cash holdings, and financial deepening: Evidence from a transitional economy. J. Bank. Financ. 2012, 36, 2868-2883. [CrossRef]

13. Wu, W.; Firth, M.; Rui, O.M. Trust and the provision of trade credit. J. Bank. Financ. 2014, 39, 146-159. [CrossRef]

14. González-Ruiz, J.; Botero-Botero, S.; Duque-Grisales, E. Financial Eco-Innovation as a Mechanism for Fostering the Development of Sustainable Infrastructure Systems. Sustainability 2018, 10, 4463. [CrossRef]

15. Ferrando, A.; Mulier, K. Do firms use the trade credit channel to manage growth? J. Bank. Financ. 2013, 37, 3035-3046. [CrossRef]

16. Allen, F.; Qian, M.; Xie, J. Understanding informal financing. J. Financ. Intermediat. Available online: https: / www.sciencedirect.com/science/article/pii/S1042957318300408 (accessed on 3 February 2019).

17. Rahaman, M.M. Access to financing and firm growth. J. Bank. Financ. 2011, 35, 709-723. [CrossRef]

18. Ge, Y.; Qiu, J. Financial development, bank discrimination and trade credit. J. Bank. Financ. 2007, 31, 513-530. [CrossRef]

19. Mundaca, B.G. Remittances. Financial Market Development, and Economic Growth: The Case of Latin America and the Caribbean. Rev. Dev. Econ. 2009, 13, 288-303. [CrossRef]

20. Alexiou, C.; Vogiazas, S.; Nellis, J.G. Reassessing the relationship between the financial sector and economic growth: Dynamic panel evidence. Int. J. Financ. Econ. 2018, 23, 155-173. [CrossRef]

21. Rajan, R.G.; Zingales, L. Financial Dependence and Growth. Am. Econ. Rev. 1999, 88, 559-586.

22. Ogawa, K.; Sterken, E.; Tokutsu, I. The trade credit channel revisited: Evidence from micro data of Japanese small firms. Small Bus. Econ. 2013, 40, 101-118. [CrossRef]

23. McGuinness, G.; Hogan, T.; Powell, R. European trade credit use and SME survival. J. Corp. Financ. 2018, 49, 81-103. [CrossRef]

24. Lin, S. China's Government Debt: How Serious? China Int. J. 2003, 1, 73-98. [CrossRef]

25. Jiang, F.; Kim, K.A. Corporate governance in China: A modern perspective. J. Corp. Financ. 2015, 32, $190-216$. [CrossRef]

26. Teng, D.; Fuller, D.B.; Li, C. Institutional change and corporate governance diversity in China's SOEs. Asia Pac. Bus. Rev. 2017, 24, 273-293. [CrossRef]

27. Wang, Q.; Wong, T.J.; Xia, L. State ownership, the institutional environment, and auditor choice: Evidence from China. J. Account. Econ. 2008, 46, 112-134. [CrossRef]

28. Liao, L.; Liu, B.; Wang, H. China's secondary privatization: Perspectives from the Split-Share Structure Reform. J. Financ. Econ. 2014, 113, 500-518. [CrossRef]

29. Cull, R.; Xu, L. Institutions, ownership, and finance: The determinants of profit reinvestment among Chinese firms. J. Financ. Econ. 2005, 77, 117-146. [CrossRef]

30. Yao, Y.; Yueh, L. Law, Finance, and Economic Growth in China: An Introduction. World Dev. 2009, 37, 753-762. [CrossRef]

31. Allen, F.; Qian, J.; Qian, M. Law, finance, and economic growth in China. J. Financ. Econ. 2005, 77, 57-116. [CrossRef]

32. Hu, H.W.; Tam, O.K.; Tan, M.G. Internal governance mechanisms and firm performance in China. Asia Pac. J. Manag. 2010, 27, 727-749. [CrossRef]

33. Costello, A.M.; Wittenberg-Moerman, R. The Impact of Financial Reporting Quality on Debt Contracting: Evidence from Internal Control Weakness Reports. J. Account. Res. 2011, 49, 97-136. [CrossRef] 
34. Skaife, H.A.; Veenman, D.; Wangerin, D. Internal control over financial reporting and managerial rent extraction: Evidence from the profitability of insider trading. J. Account. Econ. 2013, 55, 91-110. [CrossRef]

35. Feng, M.; Li, C.; McVay, S.E.; Skaife, H. Does Ineffective Internal Control over Financial Reporting affect a Firm's Operations? Evidence from Firms' Inventory Management. Account. Rev. 2014, 90, 529-557. [CrossRef]

36. DMello, R.; Gao, X.; Jia, Y. Internal control and internal capital allocation: Evidence from internal capital markets of multi-segment firms. Rev. Account. Stud. 2017, 22, 251-287. [CrossRef]

37. Bargeron, L.L.; Lehn, K.M.; Zutter, C.J. Sarbanes-Oxley and corporate risk-taking. J. Account. Econ. 2010, 49, 34-52. [CrossRef]

38. Cohen, J.; Krishnamoorthy, G.; Wright, A. Corporate Governance in the Post-Sarbanes-Oxley Era: Auditors' Experiences. Contemp. Account. Res. 2010, 27, 751-786. [CrossRef]

39. Cheng, M.; Dhaliwal, D.; Zhang, Y. Does investment efficiency improve after the disclosure of material weaknesses in internal control over financial reporting? J. Account. Econ. 2013, 56, 1-18. [CrossRef]

40. Wang, F.; Xu, L.; Zhang, J.; Shu, W. Political connections, internal control and firm value: Evidence from China's anti-corruption campaign. J. Bus. Res. 2018, 86, 53-67. [CrossRef]

41. Demirgüç-Kunt, A.; Maksimovic, V. Law, Finance, and Firm Growth. J. Financ. 1998, 53, $2107-2137$. [CrossRef]

42. CHorne, J.; Wachowicz, J.J. Fundamentals of Financial Management; Prentice Hall: Upper Saddle River, NJ, USA. Available online: https:/ / www.google.com.hk/url?sa=t\&rct=j\&q=\&esrc=s\&source=web\&cd= 1\&ved=2ahUKEwiZ6v6Jir_gAhXKFIgKHUsADCwQFjAAegQICBAC\&url=https\%3A\%2F\%2Fyamanfc. files.wordpress.com\%2F2015\%2F01\%2Ffundamentals-of-financial-management.pdf\&usg=AOvVaw23hXpCQ_yRq0mX5D8gJMn (accessed on 3 February 2019).

43. Yang, X.; Peng, C.; Yao, A. Management Capability, Internal Control and Corporate Sustainability. Audit Res. (Chin.) 2018, 3, 121-128.

44. Higgins, R. How Much Growth Can a Firm Afford? Financ. Manag. 1977, 6, 3-16. [CrossRef]

45. Lu, Z.; Yang, D. Trade Credit: Alternative Financing or Buyer's Market? Manag. World (Chin.) 2011, 4, 6-14.

46. Lang, L.; Ofek, E.; Stulz, R. Leverage, investmcmt, and firm growth. J. Financ. Econ. 1996, 40, 3-29. [CrossRef]

47. Fama, E.F.; Macbeth, J.D. Risk, Return, and Equilibrium: Empirical Tests. J. Political Econ. 1973, 81, 607-636. [CrossRef]

48. Pretty, J.; Ward, H. Social Capital and the Environment. World Dev. 2001, 29, 209-227. [CrossRef]

49. Zhang, M.; Ma, L.; Su, J.; Zhang, W. Do Suppliers Applaud Corporate Social Performance? J. Bus. Ethics 2014, 121, 543-557. [CrossRef]

50. Mian, S.L.; Smith, C.W. Accounts Receivable Management Policy: Theory and Evidence. J. Financ. 1992, 47, 169-200. [CrossRef]

51. Albuquerque, R.; Ramadorai, T.; Watugala, S.W. Trade credit and cross-country predictable firm returns. J. Financ. Econ. 2015, 115, 592-613. [CrossRef]

(C) 2019 by the authors. Licensee MDPI, Basel, Switzerland. This article is an open access article distributed under the terms and conditions of the Creative Commons Attribution (CC BY) license (http://creativecommons.org/licenses/by/4.0/). 